\title{
RUINOUS COMPETITION IN NEWS, THE POSTAL INTERNET, AND THE THREE LAWS OF TECHNO-LEGAL CHANGE
}

\author{
Ramsi A. Woodcock*
}

\begin{abstract}
Policymakers' current approach to the problem of online misinformation, which revolves around defining the circumstances under which content platforms like Twitter and Facebook may be held liable for the speech of their users, fails to get at the root cause of the problem: the low cost of communication. The theory of monopolistic competition teaches that businesses respond to low-cost entry into their markets, and the cutthroat competition it creates, by differentiating their products, sometimes in legitimate ways, but sometimes through deceit. Misinformation on the Internet has the same source: speakers using deceit to compete for attention in a highly competitive speech market. The solution, as in all cases of ruinous competition, is to replace the falling technological barriers to market entry that have given rise to the excessive competition with new legal barriers to entry.

The way to create legal barriers to online speech is not to license speech, an approach that would violate the First Amendment, but rather to treat the Internet like a brick-and-mortar postal system. In the United States, the Postal Service enjoys a "letter-box monopoly:" the exclusive right to place mail in mailboxes. This exclusivity gives the Postal Service the power to charge a price - postage - for each communication delivered to an American mailbox. The U.S. Congress - or the Postal Service itself through reinterpretation of existing law-should give the Postal Service a letter-box monopoly on social media posting: the exclusive right to charge a fee for every Tweet, Facebook post, or other social media missive delivered in America. That would greatly increase the cost of being heard on the Internet, for as the number of a poster's followers increases, the total cost of social media "postage" would increase as well, reducing competition and the incentive to misinform. Because the letter-box monopoly has survived constitutional scrutiny for two centuries, this approach would necessarily survive First Amendment scrutiny as well.
\end{abstract}

\footnotetext{
* Assistant Professor, University of Kentucky Rosenberg College of Law, Secondary Appointment, Department of Management, University of Kentucky Gatton College of Business \& Economics. This research was supported by a grant from the John S. and James L. Knight Foundation.
} 


\section{Table of Contents}

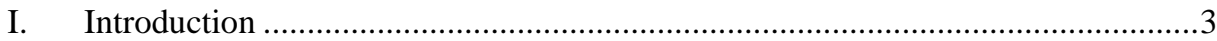

II. Three Laws of Techno-Legal Change …………...............................................

III. News Reporting as Monopolistic Competition ..............................................11

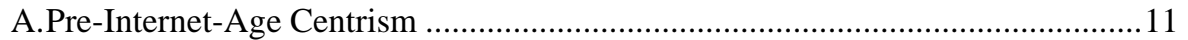

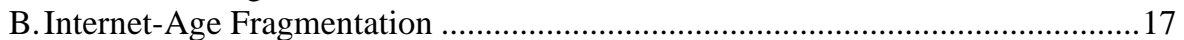

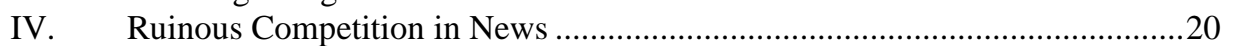

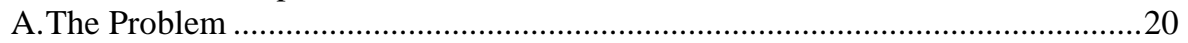

B. Regulatory Solutions for Ruinous Competition...............................................25

1. Price and Entry Regulation and Direct Regulation in Historical Perspective .25

2. Direct Regulation in the News Context Would Violate the First Amendment 28

3. Entry Regulation in the Internet Context Would Also Violate the First

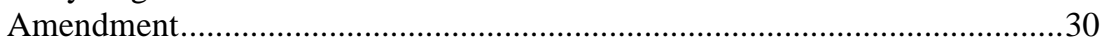

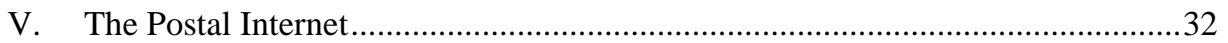

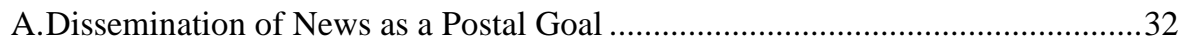

B. Using Postage to Regulate the Internet News Market ...........................................35

C. Postage for Posting, Rather Than for Internet Access ..........................................38

D.Letter-Box Monopoly as Preexisting Authority to Charge Internet Postage ........40

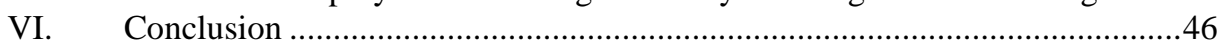




\section{INTRODUCTION}

The newspaper industry argues that the epidemic of misinformation sweeping the United States is a monopoly problem: the result of anticompetitive conduct by big tech companies. ${ }^{1}$ In fact, the opposite is true. It is the result of too much competition. The Internet and social media have driven the cost of reporting news to a national audience almost to zero, enabling virtually anyone with an Internet connection to enter the market to report news. $^{2}$

No great theoretical advance is required to understand the consequences, which basic theories of monopolistic competition invented in the 1920s predict. ${ }^{3}$ These theories hold that as new participants enter a market, they spread out, each claiming a different market niche, each niche dwindling in size as the market fills and an increasing number of competitors fight over the same space. ${ }^{4}$ Just so, the past twenty years of the Internet's maturity have been characterized by accelerating fragmentation of the national news market. ${ }^{5}$ What twenty years ago was a market dominated by a center-right paper - the Wall Street Journal - and a center-left paper-the New York Times - is now filled with a multitude of voices reaching a national audience, from right-wing news websites, to television news outlets that now also

1 See Staff, Alliance Releases New White Paper Outlining Google's Dominant Market Behavior, Harming of Journalism, NEWS MEDIA ALLIANCE, http://www.newsmediaalliance.org/release-news-media-alliance-releases-new-white-paperoutlining-googles-dominant-market-behavior-harming-of-journalism/ (last visited Oct. 25, 2020); David Chavern, Statement: News Media Alliance Applauds House Report on Dominant Online Platforms and Market Power, NEWs MEDIA Alliance, http://www.newsmediaalliance.org/statement-news-media-alliance-applauds-houseantitrust-report-dominant-online-platforms/ (last visited Oct. 25, 2020); Kate Ackley \& Kate Ackley, News Media Alliance Pushes for New Senate Antitrust Bill, (Jun. 4, 2019), https://www.rollcall.com/news/news-media-alliance-pushes-new-senate-antitrust-bill.

2 See Jean-Yves Huwart \& Loïc Verdier, Text, Economic Globalisation: Origins and Consequences 36, https://www.oecd-ilibrary.org/economics/economicglobalisation_9789264111905-en (last visited Mar. 5, 2021) (charting the decline in international calling costs, a good proxy for the decline in overall communications costs, almost to zero since 1930); Erwin Chemerinsky, Keynote Address: Fake News, Weaponized Defamation and the First Amendment, 47 SOUTHWESTERn L. REV. 291, 291 (2018).

${ }^{3}$ See generally EDWARD H. CHAMBERLIn, THE THEORY OF MONOPOLISTIC COMPETITION: A RE-Orientation OF THE THEORY OF VALUE (7th ed. 1958); Harold Hotelling, Stability in Competition, 39 ECON. J. 41 (1929).

${ }^{4}$ See Steven C. Salop, Monopolistic Competition with Outside Goods, 10 BELL J. ECON. 141, 144 (1979).

5 See Markus Prior, Media and Political Polarization, 16 AnN. REV. Pol. SCI. 101, 103 (2013). 
publish written content, to the legacy papers themselves, to the vast number of social media users with large followings who report and amplify the news, each occupying a slightly different ideological position. ${ }^{6}$

Ideological fragmentation is, in the abstract, a good thing: it means that the news market is better satisfying the preferences of news consumers, which occupy a spectrum. ${ }^{7}$ But fragmentation also has two effects that lead ultimately to misinformation. The first is that, as news organizationsincluding social media posters with large followings - crowd into the market, revenues fall, because the money spent by consumers and firms on subscriptions and advertisements, respectively, must support more market participants. ${ }^{8}$ Uncovering and verifying facts is, however, an expensive undertaking, and, as revenues fall, news organizations must invest less in facts and more in opinion reporting in order to stay solvent. ${ }^{9}$ The individual

\footnotetext{
${ }^{6}$ See id. at 103, 119 ("In the 1970s, about a quarter of Americans identified strongly with a political party. Media in the broadcast era were probably too centrist for these people's tastes. Technological change has made it economically viable to cater to smaller audience segments. Nobody should be surprised that some strong partisans turned to more ideologically congruous media formats when they became available."); How Misinformation Spreads on Social Media-And What To Do About It, LAWFARE, https://www.lawfareblog.com/howmisinformation-spreads-on-social-media-and-what-to-do-about-it (last visited Jan. 11, 2021) (discussing the effect of social media posting on dissemination of news).

${ }^{7}$ See Prior, supra note 5, at 103; Neil W. Averitt \& Robert H. Lande, Consumer Sovereignty: A Unified Theory of Antitrust and Consumer Protection Law, 65 ANTITRUST L.J. 713, 71516 (1997) (noting that the availability of a variety of options is key to maximizing consumer welfare).

${ }^{8}$ See Elizabeth Grieco, About a Quarter of Large U.S. Newspapers Laid off Staff in 2018, PEW RESEARCH CENTER, https://www.pewresearch.org/fact-tank/2019/08/01/large-u-snewspapers-layoffs-2018/ (reporting that both newspapers and "digital-native news" organizations experienced layoffs in 2018); Elizabeth Grieco, U.S. Newspapers Have Shed Half of Their Newsroom Employees since 2008, PEW RESEARCH CENTER, https://www.pewresearch.org/fact-tank/2020/04/20/u-s-newsroom-employment-hasdropped-by-a-quarter-since-2008/.

9 See Beth KnObel, The Watchdog Still Barks: How Accountability Reporting EVOLVED FOR THE DigITAL AGE (2018) (finding, based on a study of a small sample of newspapers from 1991 to 2011, that investigative stories had increased slightly in number but their contents had shifted from investigations of institutions to investigations of particular people, suggesting a reduction in the capacity of newspapers to mount broad-based investigations due to budget cuts); Book Aims to Pin down Economic Return on Investigative Reporting, COLUM. JOURNALISM REV., https://www.cjr.org/q_and_a/investigativereporting-value.php (noting that a single investigative story can cost between $\$ 200,000$ to \$300,000 to report); The Fall, Rise, and Fall of Media Trust, Colum. Journalism ReV., https://www.cjr.org/special_report/the-fall-rise-and-fall-of-media-trust.php/ (last visited Jan. 12, 2021) (noting that "mainstream outlets have increasingly emphasized analysis in news coverage"); JAMES HAMILTON, DEMOCRACY'S DETECTIVES: THE ECONOMICS OF INVESTIGATIVE JOURNALISM 27 (2018) (noting that "it is cheaper to repeat and repackage facts discovered by others"). The decline in fact reporting may be driving declines in public
} 
social media poster with a national following is an extreme example of this effect. The poster sells news at a zero price and consequently has no money to invest in verifying the news or in finding it, which is why most news reported on social media is reposted from other sources. ${ }^{10}$

The second effect of ideological fragmentation is that it makes fact reporting less effective, and opinion reporting more effective, at attracting readers. When a small number of newspapers serves a large, ideologicallydiverse market, opinion reporting is bad for business, because readers dislike the cognitive dissonance created by perspectives on the news that differ from their own. ${ }^{11}$ But all readers want the facts, albeit woven into the particular narrative each reader espouses, because the ultimate claim of every ideological position is that the position has the best purchase on reality of all positions. ${ }^{12}$ Newspapers therefore eschew opinion reporting and invest heavily in investigations. ${ }^{13}$ When a large number of newspapers each serves a small, ideologically-homogeneous piece of the ideological spectrum, however, each newspaper can hold the attention of its audience with tailored opinion reporting that is unlikely to cause dissonance because of the audience's homogeneity. ${ }^{14}$ Expensive investments in fact reporting are not

perceptions of newspaper believability. See News Media Credibility Rating Falls to a New Low, MORNING CONSUlT (Apr. 22, 2020), https://morningconsult.com/2020/04/22/mediacredibility-cable-news-poll/.

${ }^{10}$ As a result, most Americans believe that news they obtain via social media is inaccurate. See Elisa Shearer \& Katerina Eva Matsa, News Use Across Social Media Platforms 2018, Pew Research CEnTER's Journalism Project (Sep. 10, 2018), https://www.journalism.org/2018/09/10/news-use-across-social-media-platforms-2018/.

11 See Wolfgang Donsbach, Exposure to Political Content in Newspapers: The Impact of Cognitive Dissonance on Readers' Selectivity, 6 EUROPEAN JOURNAL OF COMMUNICATION 155, 157 (1991) (summarizing psychology literature showing that the degree of credibility and refutability of an argument determines the level of dissonance experienced by a reader).

12 See Amy Mitchell et al., 2. Political Leaders, Activists Viewed as Prolific Creators of Made-up News; Journalists Seen as the Ones to Fix It, PEW RESEARCH CENTER'S JOURNALISM PROJECT (Jun. 5, 2019), https://www.journalism.org/2019/06/05/politicalleaders-activists-viewed-as-prolific-creators-of-made-up-news-journalists-seen-as-the-

ones-to-fix-it/ ("Of the $76 \%$ of Americans who ever get news through social media, half have blocked a news source because they thought it was posting made-up news or information, the same proportion who say they have blocked someone they know for that reason."); Donsbach, supra note 11, at 173, 179 (finding that readers are attracted to news articles that appear newsworthy, regardless of political affiliation).

${ }^{13}$ This may be reflected in the relatively high trust in newspapers in the mid $-20^{\text {th }}$ century, when the number of news sources reaching a national audience was relatively small. See The Fall, Rise, and Fall of Media Trust, supra note 9.

${ }^{14}$ See Donsbach, supra note 11, at 157; HAMILTON, supra note 9, at 26 (noting that reporting that "describe[s] events from a partisan perspective .... may generate ... higher satisfaction with the media mix" for those who share the paper's perspective). 
required. $^{15}$

The combined result of these two effects of ideological fragmentationpressure to reduce costs and ideological homogeneity in readership - is the paradox that, in reducing the cost of communication, the Internet also reduces the amount invested by the news industry in uncovering and verifying facts, leading to the spread of misinformation. ${ }^{16}$ The problem will soon be greatly magnified by the arrival of a new generation of artificial intelligences that can write news articles and give any desired ideological "spin" to a given set of facts. ${ }^{17}$ These AIs will remove one of the last remaining costs of reporting not associated with fact development - the cost of writing — and so flood the news market with even more competitors.

It is a law of technological advance that technology removes good barriers to human action as well as bad, and another law that the only way to put back the good barriers is through legal rules. The solution to competitiondriven misinformation is therefore to use legal rules to raise the cost of communication: not back to where costs were before the Internet, for that would eliminate the gains in terms of diversity of thought that low cost communication makes possible, but high enough, relative to current levels, to bring about a reduction in misinformation.

One way to raise communications costs would be for the United States Postal Service to put a price on making Internet posts to large audiences. Anyone wishing to mass-email, tweet, Facebook-post, Whats App, or simply serve up webpages to more than, say, a thousand people at a time would be required to buy postage, with the rate set high enough to deny large audiences to any social media posters, newspapers, or news website operators that do not have a revenue stream sufficient to invest in fact investigation or verification. $^{18}$ The resulting reduction in competition would allow newspapers to invest more in the facts and increase their incentive to do so as their markets become more ideologically diverse.

The Postal Service might even be able to act unilaterally to start charging

15 See HAMILTON, supra note 9, at 131 (summarizing data on three major newspaper investigations and estimating that the costs to the newspapers of the investigations were $\$ 90,000, \$ 216,500$, and $\$ 487,000)$. A fragmented market also means fewer readers available to cover the costs of investigative reporting. See id. at 106 (noting that an investigative story is "[m]ore likely [to be] published if . . . [a l]arger number of readers [are] interested in the story," presumably because more readers are needed to cover the high fixed costs of expensive stories).

${ }^{16}$ See KNOBEL, supra note 9; HAMILTON, supra note 9, at 279-80.

${ }^{17}$ See Izabella Kaminska, GPT-3: The AI Language Tool that May Change How We Write, FiNANCIAL TIMES (Nov. 25, 2020), https://www.ft.com/content/beaae8b3-d8ac-417c-b364$383 \mathrm{e} 8 \mathrm{acd} 6 \mathrm{c} 8 \mathrm{~b}$.

${ }^{18} \mathrm{Cf}$. HAMILTON, supra note 9, at 131. 
Internet postage, because federal law currently grants the Postal Service a "letter-box" monopoly_delivering a letter to a "letter-box" without postage is a federal crime - and confers on the Postal Service the authority to define "letter." 19 By defining "letter" to include all missives delivered over the Internet, the Postal Service would obtain a virtual letter-box monopoly and with it the power to charge for the right to receive Internet communications. ${ }^{20}$ The First Amendment would not block this expansion of the letter-box monopoly because the reason given by the Supreme Court in 1981 for which the physical letter-box monopoly does not burden speech would apply with greater force to a virtual letter-box monopoly. ${ }^{21}$ The Court reasoned that the physical letter-box monopoly does not burden speech because it does not prevent groups not wishing to pay postage from slipping letters under a recipient's door. ${ }^{22}$ A virtual letter-box monopoly, particularly when used by the Postal Service to charge postage only for posts to thousands of recipients, would not restrict speech any more than the physical letter-box monopoly, and indeed would leave open speech opportunities vastly greater than those that existed in 1981.

Part II identifies laws of techno-legal change that explain the misinformation problem created by the Internet, along with its solution, in abstract terms. Parts III and IV show why misinformation is a problem of ruinous competition, and discuss policy options. Part V argues that Internet postage is a solution.

\section{Three LAws of TeChNo-Legal Change}

Technology removes constraints. It allows travel much farther in a day than legs take you. It lets you fry your enemies on the other side of the globe without needing to go out to meet them face-to-face. It lets you speak with someone in another city. And it lets anyone at all disseminate a news article to the globe at the click of a button, where just a few decades ago even the world's largest newspapers had continental distributions, at best. ${ }^{23}$

\footnotetext{
1918 U.S.C. $§ 1725$ (2018) (prohibiting delivery of "mailable matter" with a "letter box" without postage); 39 C.F.R. $§ 310.1$ (a) (Postal Service regulation defining “letter”).

${ }^{20}$ Cf. 39 C.F.R. $\$ 310.1$ (a).

${ }^{21}$ See Postal Service v. Council of Greenburgh Civic Assns., 453 U.S. 114, 126-33 (1981).

${ }^{22}$ See id. at 127 ("[W]e are not here confronted with a regulation which in any way prohibits individuals from going door-to-door to distribute their message or which vests unbridled discretion in a governmental official to decide whether or not to permit the distribution to occur.").

${ }^{23}$ See Katharine Q. Seelye, Newspaper Circulation Falls Sharply, N.Y. TIMES (Oct. 31, 2006), https://www.nytimes.com/2006/10/31/business/media/31paper.html (noting that peak newspaper circulation in the United States, which came in 1984, was only 63 million).
} 
The removal of constraints is the creation of power. It allows the doing of what could not be done before. But power is almost always a blunt moral instrument: it can be used for good or for ill. The power to travel can bring parents to their children or the assassin to his victim. The power to destroy remotely can fight good wars and bad. The power to talk on the phone is the power to make emergency calls or crank calls. And the power to publish globally is the power to inform or misinform. The first principle of technolegal change is therefore that technology removes constraints, both the bad constraints that society wants to remove, and the good constraints that society would rather have kept in place.

The second law of techno-legal change is that the good constraints can only be restored through legal rules. Once the knowledge how to travel farto build planes, trains, and automobiles-has been acquired, the technological constraint on travel that existed from the dawn of time right up until that moment disappears forever (unless the knowledge is somehow lost), and so the only remaining constraint is one of human will. The only questions are whether someone will choose to apply the knowledge to make the thing, and, once made, how the thing will be used. These problems of human decision-making are the province of the law, which constrains decision-making. ${ }^{24}$ If the law prohibits the manufacture of planes, trains, or automobiles, then there will be none. If the law prohibits their use to ferry drugs, then they will not be used for that purpose. The replacement of the physical constraint - the technological constraint - with a legal constraint exists even when a choice is made to alter a technology to prevent its abuse. The safety feature on a gun is not really a technological constraint, for guns can be made without it, but rather a legal constraint technologically enforced. ${ }^{25}$

Thus it may be said that the process of technological advance is a process of transformation of physical constraint into legal constraint, of nature into regulation. ${ }^{26}$ One starts with some category of activity that is off-limits in its entirety for physical reasons. Muscle does not permit long-distance travel in

\footnotetext{
${ }^{24}$ Cf. Lyria Bennett Moses, Why Have a Theory of Law and Technological Change, 8 MinN. J. L. SCI. \& TECH. 589, 594 (2007) ("Before something becomes possible, there is no need to decide how it is treated under existing legal rules or whether it ought to be permitted, prohibited, required, or encouraged. These questions arise [with increasing urgency] when a new technological development is conceived, developed, and diffused into society.").

${ }^{25} C f$. LAWRENCE LESSIG \& LAWRENCE LeSSIG, CODE 138 ( $2 \mathrm{~d}$ ed. 2006).

${ }^{26}$ Cf. Moses, supra note 24, at 594 ("The current state of technology limits, in practice, what actions we can perform, what objects we can create, and what relationships we can form. It is thus common for technological change to impact the law, which limits what actions we may perform, what objects we may create and use, and what relationships will be recognized.").
} 
short time spans, for example. Then technology eliminates the constraint, at which point the law steps in to reimpose it, not, usually, entirely, but piecemeal: in the places in which the removal of the constraint leads to bad conduct, but not in the places in which the removal of the constraint leads to good conduct. $^{27}$

The third law of techno-legal change is that the process of converting physical constraints to legal constraints is entropic: some freedom always leaks out because legal rules cannot impose constraints as absolute as physical constraints. ${ }^{28}$ The law may not want criminals to fly, but only not inventing the airplane ensures absolutely that they will not fly. Once the plane is invented, criminals will fly. This is of course most obvious when the law permits the manufacture of planes, for then the government must screen passengers, and the government will make mistakes. But this principle holds even when the government chooses not to develop the technology in order to try to ensure that no criminals fly. ${ }^{29}$ This will be more effective than the first approach, but ultimately it, too, will fail so long as someone knows how to make airplanes. For then eventually someone will make an airplane and eventually a criminal will fly on it. The principle of nuclear nonproliferation provides a nice illustration of the tendency of ideas to propagate notwithstanding strict rules of secrecy. Despite the success of the United States at being first to produce a bomb, American policymakers concluded immediately that because the principles required to make a bomb were "well known to competent scientists throughout the world" the best that could be hoped was to delay proliferation through international agreements. ${ }^{30}$ The root problem is the semi-governable and rebellious character of human society. ${ }^{31}$ The absence of a hive mind makes governance always imperfect, in contrast to the perfection of physical constraint - or one might say, the perfection of ignorance. When no one knows how to do a thing no one will do it. When one is told not to do a thing, someone will do it.

The imperfection of governance means that technological advance

\footnotetext{
${ }^{27}$ See id. at 594-95 ("We need to regulate certain new forms of conduct and new, specially tailored laws are required to do this. In some cases, it may even be appropriate to ban a particular technology or particular applications of that technology.").

${ }^{28}$ Cf. 1 Richard P. Feynman et AL., The Feynman LeCtures ON Physics 44-3 (2006) (" $[\mathrm{H}]$ eat [read: freedom] cannot be taken in at a certain temperature and converted into work [read: subjected to law] with no other change in the system or the surroundings [read: without some freedom escaping the law].").

${ }^{29} \mathrm{Cf}$. Moses, supra note 24, at 594-95 (alluding to the banning of technology).

${ }^{30}$ See NichOlAS L. Miller, STOPPING THE BOMB: THE SOURCES AND EFFECTIVENESS OF US NONPROLIFERATION POLICY 1 (2018).

${ }^{31}$ See Natalie Angier, Edward O. Wilson's New Take on Human Nature, SMITHSONIAN MAG., https://www.smithsonianmag.com/science-nature/edward-o-wilsons-new-take-onhuman-nature-160810520/ (last visited Mar. 6, 2021).
} 
always leads to a net reduction in regulation in the sense that in the process of moving from being subject to the absolute law of nature to being subject to imperfect human law a bit of freedom to break the law seeps out of the system and indeed seeps out to an extent equal to the imperfection of human law. ${ }^{32}$ The criminal who could not travel at all now can travel, if he escapes detection by human law. Of course, the move to human law also enables many non-criminals to travel for the first time, and in this sense technology brings freedom too. But this is not the sense of freedom of interest here, for non-criminals can travel only because the human and natural law now permit it thanks to the advance of technology. The real freedom created by technological advance is the freedom to break a human law that once could not be broken because it was also a physical law.

This may seem not to account for technologies that enhance the power of the state to enforce legal rules - the surveillance technologies, and the weapons. ${ }^{33}$ Does not technology make law stronger and reduce the freedom to break the law, rather than increase it? To be sure, these enforcement technologies can increase enforcement of human law, but they do not undermine the principle of techno-legal entropy, which, like the entropy of the laws of physics, is defined with respect to a particular reference frame. ${ }^{34}$ Enforcement technologies must be considered in relation to the natural constraints that these technologies eliminate, not in relation to the natural constraints that the legal rules they are used to enforce are intended to recreate. Judged in relation to the natural constraints they eliminate, enforcement technologies do increase freedom, for it must be said that enforcement technologies enable both good and bad conduct by enforcersthe government can surveil both to protect and to oppress, for example - and the law cannot prevent all misuses of enforcement technologies from taking place. ${ }^{35}$ But misuse is freedom. The intelligence agency that spies on the people over the Internet, in violation of legal rules against doing so, does something that it simply could not do before the Internet. ${ }^{36}$

\footnotetext{
${ }^{32}$ Cf. Moses, supra note 24, at 596 (arguing that "[s] uggestions that law is unable to keep up in a race against technology or that law does not apply to a new technology such as the Internet" are overstated).

${ }^{33}$ See Arthur J. Cockfield, Towards a Law and Technology Theory CALT Conference: What is Legal Knowledge, 30 MAN. L.J. 383, 386 (2003).

34 See Dilip KONDEPUd, MODERn THERMODYNAMICS: FrOM HEAT ENGINES TO DisSIPATIVE STRUCTURES 84-92 (1998).

35 See Cockfield, supra note 33, at 386. Those emphasizing the ability of technology to substitute for or even improve upon the law accordingly miss something important about technological change. See LESSIG \& LESSIG, supra note 25, at 138; Cockfield, supra note 33, at 405-6.

${ }^{36} C f$. Cockfield, supra note 33 , at 386.
} 
Enforcement technologies do also improve enforcement of legal rules, and that can reduce the amount of freedom of action created by the technologies those other rules seek to regulate, but no enforcement technology can perfect enforcement. ${ }^{37}$ Behind all technology lies a human decider, and one day the decider will not behave as required for the law perfectly to be enforced. No amount of technological advance-save one that makes of the human a hive mind - can completely eliminate the imperfection of governance. ${ }^{38}$ Thus while enforcement technologies may drive relative improvements in governance - cameras do make it easier to catch killers who use guns - there is always an absolute increase in freedom as technology advances - killers who use guns are enabled by guns, and some such killers will always slip through the surveillance net, and the surveillance itself will always be abused, both outcomes that would have been impossible if guns and cameras had not been invented.

In the same way, some energy always escapes from a physical system. ${ }^{39}$ While the system can become more efficient in the use of its energy source, and that in turn can be due to application of energy into the system - the work done to improve the efficiency of a spring, for example - no closed system can ever prevent the leakage out of some energy. ${ }^{40}$ There are no perpetual motion machines. ${ }^{41}$ Thus the move from natural law to human law, like the motion of the swing attempting to restore a falling child to the height at which she started, can never quite recreate the perfection in enforcement achieved under natural law, just as, without a push on the way up, the swing will never get the child back to where she started. ${ }^{42}$ In this sense, technological advance always represents a breakdown in governance. This is the techno-legal law of entropy.

\section{NEWS REPORTING AS MONOPOLISTIC COMPETITION}

\section{A. Pre-Internet-Age Centrism}

The Internet of course eliminates a major natural constraint on communication, making it possible to reach virtually anyone digitally, rather than through the laborious process of distributing physical bits of paper. ${ }^{43}$

\footnotetext{
${ }^{37}$ Cf. LESSIG \& LESSIG, supra note 25, at 138.

${ }^{38}$ See Angier, supra note 31.

${ }^{39}$ See KONDEPUDI, supra note 34, at 98.

${ }^{40}$ See id.

${ }^{41}$ See 1 FEYNMAN ET AL., supra note 28, at 4-2.

${ }^{42}$ See id. at 4-2-4-3.

43 See Scott Wallsten, Cloud Computing: Co-Invention for the Masses, THE TECHNOLOGY PoliCy InstituTE (Jul. 19, 2018), https://techpolicyinstitute.org/2018/07/19/cloud-
} 
The trouble is that this new power enjoyed by anyone to communicate with everyone-for, in principle, everyone can see what you post publicly on the Internet - can lead to good, factual, communication and bad, false communication - that is, to misinformation. ${ }^{44}$ The (imperfect) solution to the problem is to replace the natural constraints on communication that limited the spread of misinformation before the Internet with legal constraints. The techno-legal law of entropy (the third law) tells us that the Internet inevitably brings with it a net increase in misinformation, at least with respect to the voices that the Internet allows to be heard but which could not be heard before. ${ }^{45}$ No matter what the law does, the Internet will enable some false speech that was not possible before. ${ }^{46}$ That does not mean, however, that the law cannot be used to minimize the amount of new misinformation created by the technology.

But what exactly were the natural constraints that once limited misinformation before the Internet age? And how best can the law now restore some of them without destroying the opportunity for good, factual, communication created by the Internet? To answer these questions we must understand how the news market functions.

computing-co-invention-for-the-masses/ (charting massive declines in the cost of processing, storing, and transmitting data over the Internet over the past twenty years); Wikipedia: History of United States postage rates (2021) (showing that inflation-adjusted U.S. postage rates have remained approximately constant for the past 140 years).

44 See Emily K. Vraga \& Leticia Bode, Defining Misinformation and Understanding Its Bounded Nature: Using Expertise and Evidence for Describing Misinformation, 37 POLITICAL COMMUNICATION 136, 2-3 (2020) (defining misinformation as "confident, yet inaccurate knowledge"); Mary Blankenship, How Misinformation Spreads Through Twitter 4, https://www.brookings.edu/blog/up-front/2020/07/06/how-misinformation-spreads-ontwitter/.

${ }^{45}$ In theory, the Internet might reduce overall misinformation, if it places constraints on misleading speech that did not exist before, by, for example, facilitating peer review and content moderation, with the result that some preexisting speech that would have been misleading before the Internet now can no longer be misleading. But that reduction in misinformation would not be due to the removal of a technological constraint, but rather to the creation of a technological constraint; thus, in a sense, were the Internet to reduce opportunities for misinformation in preexisting speech, the Internet would not count as a technological advance at all with respect to that speech, but rather as a technological decline, for it would create constraint rather than eliminate it. But the Internet surely enables a great deal of new speech, and some of that speech will be misleading. It is here, in the new speech made possible by the Internet, that one finds technological advance and the techno-legal law of entropy in action.

${ }^{46}$ For reasons to be explained shortly, the Internet might also cause some true speech that might once have been delivered not to be delivered after all, which is also a kind of misinformation by omission. See Sille Obelitz Søe, Algorithmic Detection of Misinformation and Disinformation: Gricean Perspectives, 74 JOURNAL OF DOCUMENTATION 309, 323-323 (2018) (noting that misinformation can be a product of omission of facts). 
The news market is best understood in the monopolistic competition framework that has been used to describe everything from competition between pizza places on the Atlantic City boardwalk, to competition between brands of breakfast cereal, to competition between political parties. ${ }^{47}$ In this framework, consumer tastes occupy a spectrum, from the top of the boardwalk to the bottom in the case of Atlantic City pizzeria locations, from healthful to sweet in the case of breakfast cereals, and from left to right in the case of political parties and also the news market considered here. ${ }^{48}$ Firms compete by choosing where to locate along the spectrum. ${ }^{49}$ They choose where to locate on the boardwalk, whether to be a sweet or healthful cereal, and whether to report the news in a left wing, right wing, or centrist fashion, or something in between. ${ }^{50}$ Location matters because consumers are assumed to patronize the enterprise that locates closest to them. ${ }^{51}$ Thus a right-winger will buy the right wing paper, but if there is none, then the centrist paper, and if there is no centrist paper either, then the leftist paper as a last resort. ${ }^{52} \mathrm{~A}$ firm wishing to attract right wing business will tack right, reporting on topics that concern right-wingers, and presenting facts in ways that please right wingers. ${ }^{53}$ But, importantly, the paper need not tack all the way right in order to win right wing business. Instead, the paper need only move slightly to the right of its right-most competitor, for so long as the paper is the rightmost of the market, right-wing readers will buy it even if the paper is substantially to their left, for lack of an alternative. Just so, a beachgoer will walk the length of the boardwalk, if necessary, to get to the closest pizza place. ${ }^{54}$

The fact that people will travel significant distances to reach the firm closest to them on the preference spectrum had an important implication for the newspaper market before the rise of the Internet. ${ }^{55}$ Back then, the cost of distributing newspapers was substantial, so a given newspaper market-let us consider the national market here-could only support a limited number

\footnotetext{
${ }^{47}$ See Hal R. VARIAn, InTERmediate Microeconomics: A Modern ApProACH 463-66 (7th ed. 2006); Richard Schmalensee, Entry Deterrence in the Ready-to-Eat Breakfast Cereal Industry, 9 BELl J. ECON. 305, 308-10 (1978); A. Downs, An Economic Theory of Political Action in a Democracy, J. POL. ECON. 141-45 (1957).

${ }^{48}$ See HAMILTON, supra note 9, at 19-22 (employing a spatial product differentiation model to describe the news industry).

${ }^{49}$ See id.

${ }^{50}$ Cf. Joel Waldfogel, Preference Externalities: An Empirical Study of Who Benefits Whom in Differentiated-Product Markets, 34 RAND J. ECON. 557, 558 (2003).

${ }^{51}$ See VARIAN, supra note 47, at 464.

${ }^{52}$ See id. at 463-66.

${ }^{53}$ See id.

${ }^{54}$ See id. at 463-64.

${ }^{55}$ See id. at 463-66.
} 
of newspapers. ${ }^{56}$ The collective willingness of newspapers and advertisers to pay could only cover the printing and distribution costs of, say, two national newspapers. ${ }^{57}$ One might have expected these two newspapers to occupy opposing ends of the political spectrum - one the far left and the other the far right. But the fact that consumers choose the paper closest to their tastes implies that newspapers will actually bunch up in the political center. ${ }^{58} \mathrm{~A}$ firm that occupies one extreme - say, the right - will lose the entire market if the other firm locates just to its left. ${ }^{59}$ The first firm will respond by relocating just to the left of the second, and the second will respond by moving to the left of the first. ${ }^{60}$ In this way, they will inch along the spectrum until they reach the center. ${ }^{61}$ At this point the inching will stop because one paper will take all the business from one half of the market and the otherthe one closest to the other half-will take all of the business from that half of the market. ${ }^{62}$ Neither will try to change position further because doing so reduces sales. ${ }^{63}$ The rightmost firm that moves left now cedes the entire right half of the field in order to move left of a firm that has the entire left half, which means that the first firm will end with something less than the entire left half. ${ }^{64}$ But half of a market is more profitable than less than half of a market, regardless which sides of the political spectrum those portions occupy. ${ }^{65}$

Thus the constraint on communication associated with dissemination of the news on paper, and the resulting limit on the number of firms that can enter the market, drives newspaper coverage to the political center, rather than to extremes. The same phenomenon explains the enduring centrism of the nation's political parties. ${ }^{66}$ The United States has a winner-take-all presidential selection process, in which the candidate that gets the majority

\footnotetext{
56 See Eli NoAm, Media OwnershiP ANd CONCENTRATION IN AMERICA 36 (2009); Local Monopoly in the Daily Newspaper Industry Comment, 61 YALE L.J. 948, 948-49 (1952). Network effects also drive concentration in news markets. See NoAM, supra, at 36.

57 Cf. Waldfogel, supra note 50, at 558 ("A product is viable if it attracts enough total customers so that revenue covers fixed costs.").

58 See VARIAN, supra note 47, at 463-65. The argument assumes that consumers are evenly distributed across the political spectrum, but the result also holds if most consumers are politically centrist.

${ }^{59}$ See id.

${ }^{60}$ See id.

${ }^{61}$ See id.

${ }^{62}$ See id.

${ }^{63}$ See id.

${ }^{64}$ See id.

65 See id.

${ }^{66}$ See Jonathan Gruber, Public Finance and Public Policy 228-31 (2005).
} 
of electors wins. ${ }^{67}$ As a result, the cost of running a political party is high: the party must incur the costs of communicating with at least half of the electorate (or nearly so) to win. ${ }^{68}$ There are therefore only a small number of viable parties - two, actually - and they cluster at the center of the political spectrum to maximize their appeal. ${ }^{69}$ In many European countries, by contrast, smaller parties can play kingmaker in the appointment of governments, so the cost of running a successful party is lower, and so one sees more political parties and more ideological diversity. ${ }^{70}$

This centrism of the pre-Internet newspaper market had an important implication for the accuracy of reporting: it promoted it. ${ }^{71}$ The reason is that facts are ultimately the only part of reporting that is indispensable to every consumer, regardless of location along the political spectrum. ${ }^{72}$ A particular set of facts may be repugnant to a right-wing reader, but so long as a newspaper can establish them to be true, both sides will feel compelled to incorporate them into the preferred narrative of each. ${ }^{73}$ This may seem implausible at a moment of political polarization, when both the right and the left seem intent on denying certain facts. ${ }^{74}$ But it is important to distinguish between the extreme contestation of facts-asking for more evidence than seems reasonable - and the outright renouncement of any interest in knowing the facts. The latter is in fact quite rare, because all sides correctly view reality as the ultimate test of the righteousness of their respective positions. The truth, then, is the ultimate centrist product, the mode of reporting most likely to sell to all sides of the political spectrum, rather than just one or the other, and so we should expect that newspapers that are forced, by entry

\footnotetext{
${ }^{67}$ See U.S. Const. amend. XII.

${ }^{68}$ Communication often takes place over time, rather than all at once in a given election cycle.

${ }^{69}$ See GRUBER, supra note 66, at 228-31.

70 See Michael Gallagher Et AL., Representative GovernMEnt In Modern Europe 52-53, 196 (2011).

${ }^{71}$ See Prior, supra note 5, at 103 (noting that studies show that media leaned only slightly democratic between 1968 and 1996).

${ }^{72} \mathrm{Cf}$. Donsbach, supra note 11, at 180 (finding that in addition to political affiliation, the emphasis placed on news in a newspaper--for example, through large headlines--was a strong predictor of a reader's interest in a particular article, suggesting that important news matters to readers, regardless of political affiliation).

73 This may explain why most Americans continue to make news consumption decisions based on factual accuracy. See Mitchell et al., supra note 12 ("Of the $76 \%$ of Americans who ever get news through social media, half have blocked a news source because they thought it was posting made-up news or information, the same proportion who say they have blocked someone they know for that reason.").

${ }^{74}$ See Amy Mitchell et al., Political Polarization \& Media Habits, PEW RESEARCH CENTER'S JOURNALISM PROJECT (Oct. 21, 2014), https://www.journalism.org/2014/10/21/politicalpolarization-media-habits/.
} 
barriers into the market, to occupy a centrist position in the market will compete with each other by investing heavily in accuracy of reporting. ${ }^{75}$

The argument here is not that political centrism is factually more accurate than leftism or rightism. The facts have a tendency of supporting one side and then the other. Instead, the argument is that firms can increase the frequency with which consumers in their slice of the ideological spectrum read their papers by appealing to consumers along other dimensions that are orthogonal to ideology. One of those is the facts: consumers of all ideological stripes want to know the facts, and they will buy a scoop. ${ }^{76}$ But the generation of reliable facts is one of the most expensive parts of the news business. ${ }^{77} \mathrm{~A}$ single investigative story can take years to research and teams of reporters to complete. $^{78}$

A less expensive approach to increasing the frequency with which readers buy papers is to provide opinion reporting that weaves existing or easily uncovered facts more seamlessly into the ideological narrative preferred by the paper's readers. ${ }^{79}$ As the size of the ideological spectrum served by a paper increases, however, readership development via opinion writing becomes almost impossible because the ideological views of the readership become too diverse. ${ }^{80}$ Papers can try to deal with this by playing big tent to a range of columnists, and engaging in he-said-she-said reporting of facts, but the more diverse the views contained in the paper the less readers are likely to commit to the paper on ideological grounds. ${ }^{81}$ Readers dislike ideological diversity and the cognitive dissonance it creates. ${ }^{82}$ It follows that in news markets with a small number of players, each serving a broad swath of ideology because firms cluster in the center, competition will tend to be competition for facts rather than competition for ideology. ${ }^{83}$ The news pages

\footnotetext{
75 See Michael Schudson, Discovering the News: A SOCIAL History OF AMERICAN NEWSPAPERS 5-8 (2011) (discussing the rise of the objectivity ideal in American journalism after World War I).

${ }^{76}$ See Mitchell et al., supra note 12; Donsbach, supra note 11, at 180.

77 See HAMILTON, supra note 9, at 179 ("It has always been cheaper to repeat the news than to make it.").

78 See id. at 112-35 (giving three examples in which investigations cost between $\$ 90,000$ and $\$ 487,000)$.

${ }^{79}$ See Donsbach, supra note 11, at 157; HAMILTON, supra note 9, at 26 (noting that reporting that "describe $[\mathrm{s}]$ events from a partisan perspective . . . . may generate . . . higher satisfaction with the media mix" for those who share the paper's perspective).

${ }^{80}$ See Donsbach, supra note 11, at 157 (summarizing psychology literature showing that the degree of credibility and refutability of an argument determines the level of dissonance experienced by a reader).

81 See id.

${ }^{82}$ See id.

${ }^{83}$ Cf. Jennifer Kavanagh et al., News in a Digital Age: Comparing the Presentation of News
} 
will be the key to the business, the opinion pages much less so. ${ }^{84}$ In the preInternet-age movie The Paper, the fictional editor grouses to his staff that he has too many columnists, and the only good columnist is a dead columnist. ${ }^{85}$ This reflects the pre-Internet age newspaper wisdom that facts sell papers, not opinion reporting. ${ }^{86}$

\section{B. Internet-Age Fragmentation}

The coming of the Internet exploded the natural barriers to entry into news that had kept the number of newspapers that could fit in the market small. The cost of distributing news went almost to zero, because now posting a news item on the web could potentially reach everyone-no printing or distribution costs were involved. ${ }^{87}$ The result was that bloggers, tweeters, and other social media posters entered the news reporting market to compete with the legacy papers. ${ }^{88}$ Few could, of course, match the scope of the legacy papers' reporting; they did not, like the New York Times, have an "arts and living" section, an international section, and a sports section. But that did not matter because the low cost of communication on the Internet made it easy to consume news reports from multiple providers, something greatly facilitated by the artificial-intelligence-curated "feeds" of posts provided by social media platforms. ${ }^{89}$ These feeds in effect assembled for users a paper's worth of news from the independent posts of other users. ${ }^{90} \mathrm{~A}$ host of more traditional news organizations also entered the marketwebsites from Gawker to BuzzFeed to Axios, not to mention television news outlets that started posting written content to their websites-each reaching

Information over Time and Across Media Platforms 119 (2019) (stating that since 2020 "news coverage has shifted away from a more traditional style characterized by complex, detailed reporting that emphasizes events, context, public figures, time, and numbers toward a more personal, subjective form of reporting that emphasizes anecdotes, argumentation, advocacy, and emotion").

${ }^{84}$ Cf. id.

${ }^{85}$ See The Paper Script - Transcript from the Screenplay and/or Ron Howard Movie with Michael Keaton and Robert Duvall, http://www.script-o-rama.com/movie_scripts/p/paperscript-transcript-michael-keaton.html (last visited Jan. 12, 2021) ("I hate columnists! Why do I have all these columnists? I got political columnists, guest columnists . . . celebrity columnists -- The only thing I don't have is a dead columnist. That's the kind I could really use.").

${ }^{86}$ Cf. Kavanagh et al., supra note 83, at 119.

${ }^{87}$ See Wallsten, supra note 43.

${ }^{88}$ See Kavanagh et al., supra note 83, at 1-2, 5-7.

${ }^{89}$ See MARK Coddington, AgGRegating the News: SeCONDHAND KNOWLEDGE AND the EROSION OF JOURNALISTIC AUTHORITY chapter 1 (2019).

${ }^{90}$ See id. 
a national audience in a way that had been possible before only for two or three newspapers. ${ }^{91}$

The monopolistic competition model teaches that as the number of firms in the market increases, centrism disappears. ${ }^{92}$ To return to our example of the previous section, if a third firm enters the market, the firm will not locate at the center in between the other two firms, because then the new firm will have no market. ${ }^{93}$ The right half of the market will go to the rightmost paper and the left half to the leftmost. ${ }^{94}$ The new firm will instead choose to locate either slightly to the left of the leftmost or slightly to the right of the rightmost, taking a bit less than the entire half of the market. ${ }^{95}$ That will cause its neighbor to move in the same direction and competition will drive them both along the spectrum until they find a new "center" within the half of the spectrum that they have been contesting. ${ }^{96}$ The third firm will also share in that half, however, because those readers closest to the true center of the spectrum will buy from the firm that remains at the true center. ${ }^{97}$ This third firm therefore ends up with more than half of the market, while the other two split a position that is less than half. ${ }^{98}$

That creates an opportunity for one of the first two firms to relocate to the other side of the spectrum, because splitting more than half of the market results in a larger share of the market than splitting less than half of the market. ${ }^{99}$ One of the firms will therefore relocate to the other side of the spectrum, and after some additional competitive adjustments, one firm will continue to occupy the center and the other two will be equidistant from the center on either side. ${ }^{100}$ Most papers will therefore no longer be centrist but will instead cater to one side of the ideological spectrum or the other. Of equal importance, the share of the market served by each firm will fall: where once each firm served half the market, now each firm will serve only one

\footnotetext{
${ }^{91}$ See Mitchell et al., supra note 74.

${ }^{92}$ See VARIAN, supra note 47 , at 466.

${ }^{93}$ See id. at 463-65.

${ }^{94}$ See id.

95 See id.

96 See id.

${ }^{97}$ See id.

${ }^{98}$ See id.

${ }^{99}$ See id.

100 This symmetric equilibrium will technically be reached only if the spectrum is actually a circle, with extremists on the left merging around into extremists on the right. See Salop, supra note 4, at 143, 145-48; VARIAN, supra note 47, at 466. There is some reason to suppose that this is the case. See JeFF TAYlor, Where Did THE PARTY Go?: WILliam JenNINGS BRYAN, HUBERT HUMPHREY, AND THE JEFFERSONIAN LEGACY 118-19 (2006) (likening the political spectrum to a horeshoe in which extreme left and extreme right almost meet).
} 
third. ${ }^{101}$ As more firms enter the market, these effects magnify. ${ }^{102}$ Firms will spread out across the spectrum, each occupying an increasingly tiny ideological slice equal in size to that occupied by each of the other firms, with the centrist position becoming just one among a large number of ideological options. ${ }^{103}$

The result is not ideological polarization-newspapers do not cluster at the ideological extremes - but rather ideological fragmentation, with each point on the ideological spectrum having a source of news tailored to it. ${ }^{104}$ This is what we have seen in the Internet age. ${ }^{105}$ A national news market that was dominated by two major newspapers, the Wall Street Journal serving the right from a centrist position and the New York Times serving the left from a centrist position, gave way to a profusion of web-based news sources each serving a different ideological sliver. ${ }^{106}$ The Wall Street Journal has, at least in its news pages, continued to occupy the center, serving up new stories in a studiedly agnostic tone. ${ }^{107}$ While the Times has tacked left, joined by a slew of new entrants. ${ }^{108}$ On the right, The Wall Street Journal has been joined by Fox News, Breitbart, the New York Post-now a national paper thanks to Internet distribution - and so on. For decades readers on the left and the right complained that they could find no ideological home in the press. ${ }^{109}$ Noam Chomsky famously observed that his dentist realized that reading the New

${ }^{101}$ See VARIAN, supra note 47, at 463-65.

102 See Waldfogel, supra note 50, at 558.

103 See id.

${ }^{104}$ See id. (noting that "the number of products in the market will be proportional to total population").

105 See Hamilton, supra note 9, at 315 ("Costly delivery and distribution methods once meant consumer, producer, entertainment, and voter information came bundled in a dominant local newspaper or widely viewed national broadcast. Cable, Internet, and social media broke the bundle, making a wider variety of entertainment and expression possible. This also reduced bundling's support for information with relatively higher costs, . . . namely accountability journalism.").

${ }^{106}$ See Mitchell et al., supra note 74; Matthew Gentzkow \& Jesse M. Shapiro, What Drives Media Slant? Evidence From U.S. Daily Newspapers, 78 ECONOMETRICA 35, 40 (2010) (identifying the New York Times and the Wall Street Journal, along with USA Today and Christian Science Monitor, as the only American newspapers having an "ill defined" geographic market for purposes of a studying using 2005 data).

107 See Mitchell et al., supra note 74; AllSides Media Bias Chart, ALLSIDES, https://www.allsides.com/media-bias/media-bias-chart (last visited Jan. 12, 2021).

108 See Mitchell et al., supra note 74.

109 See Prior, supra note 5, at 119 ("In the 1970s, about a quarter of Americans identified strongly with a political party. Media in the broadcast era were probably too centrist for these people's tastes. Technological change has made it economically viable to cater to smaller audience segments."). 
York Times caused him to grind his teeth. ${ }^{110}$ But no one can complain about that today. ${ }^{111}$ If they want reporting that parses the facts in a way that is agreeable to them, they can find it. ${ }^{12}$

\section{RUINOUS COMPETITION IN NEWS}

\section{A. The Problem}

From an economic perspective, market fragmentation-also called product differentiation - is one of the virtues of competition: it leads to products that more tightly fit the preferences of consumers. ${ }^{113}$ But economists have long recognized that competition can have a dark side, particularly in industries such as Internet-age news that have very low marginal costs - writing up a news story is fairly cheap, and transmitting another news story costs almost nothing - but substantial fixed costsuncovering new facts remains costly, and the costs must be incurred before a newspaper can sell any papers (or advertisements in them). ${ }^{114}$ Normally competition, even heavy competition, will not drive prices below production costs, because every firm in the market would rather exit the market than make a loss by charging a below-cost price, so no firm is willing to take the lead and charge a below-cost price. ${ }^{115}$ As a result, firms normally do not need to worry that competition will lead to losses, only that it will prevent them from making profits in the economic sense of income beyond the amount strictly necessary to make them willing to be in the market. ${ }^{116}$ But when a firm has high fixed costs - costs that must be incurred before any units can be sold - competition can expose firms to losses without driving the firm from the market, at least in the short term. ${ }^{117}$

That is because, in such a case, even after price falls below cost, firms will remain in the market, continuing to sell so long as price covers marginal cost. ${ }^{118}$ They will do that because then every penny of income above

\footnotetext{
110 See The Chomsky Paradox, COUNTERPUNCH.ORG, https://www.counterpunch.org/2014/09/26/the-chomsky-paradox/ (last visited Jan. 12, 2021).

111 See Prior, supra note 5, at 119.

112 See AllSides Media Bias Chart, supra note 107.

113 See Averitt \& Lande, supra note 7, at 715-16.

114 See NOAM, supra note 56, at 36.

115 See VARIAN, supra note 47, at 404 (stating that "firms that are losing money exit the industry").

${ }^{116}$ See id. at 412-13.

117 See Lloyd G. Reynolds, Cutthroat Competition, 30 AM. ECON. REV. 736, 737-38 (1940).

118 See VARIAN, supra note 47, at 403 ("Even if a firm is making negative profits, it will still
} 
marginal cost can be used to pay down the debt incurred by the firm on the fixed costs, even if prices are too low to allow the paying off of the entire debt. ${ }^{119}$ It might cost a news website $\$ 10$ million per year to maintain an investigative staff capable of uncovering news, but the marginal cost of writing up and distributing another news story might be $\$ 500$. In that case, the website would be willing to run additional articles so long as the articles generate an additional $\$ 501$ in advertising revenues per article, even though the (quasi-) profit of $\$ 1$ per article might be far too little to recoup the $\$ 10$ million investment, because it would still allow recoupment of some part of the investment. ${ }^{120}$ That is better than exiting the market and recouping no part of the investment. ${ }^{121}$ So firms with high fixed costs and low marginal costs can compete prices so low that they fail to cover their total costs. ${ }^{122}$

This is what economists call "ruinous" or "cutthroat" competition. ${ }^{123}$ It can lead not only to bankruptcy for firms but, more importantly for our purposes, it can create an incentive for firms to try to keep costs down by reducing product quality and disguising those reductions, fooling customers into purchasing products that they think are good quality but which really are not. ${ }^{124}$ In consumer products markets, this leads firms to substitute lowquality ingredients for high-quality ingredients when consumers are not able to determine independently when a switch has been made. ${ }^{125}$ The same logic has long created concerns that bus or plane operators will reduce investments in safety. ${ }^{126}$ Bus and plane transportation have high fixed costs and low marginal costs - it costs a lot to buy a plane but almost nothing to add an additional passenger to a flight - and a passenger cannot independently observe whether a jet engine has been properly maintained. ${ }^{127}$

be better for it to stay in business in the short run if the price and output combination lie above the average variable cost curve. For in this case, it will make less of a loss by remaining in business than by producing a zero level of output."); Spurgeon Bell, Fixed Costs and Market Price, 32 THE QUARTERLY JOURNAL OF ECONOMICS 507, 511 (1918) ("If a new customer can be had at prices above the cost of goods sold plus additional expense it will pay to reduce prices to that point even though the fixed expenses are not covered.").

119 See VARIAN, supra note 47, at 403.

${ }^{120}$ See id.

${ }^{121}$ See id.

122 See id.

123 See Reynolds, supra note 117, at 737-38.

${ }^{124}$ See Bahram Adrangi et al., Airline Deregulation, Safety, and Profitability in the U.S., 36 TRANSP. J. 44, 44-45 (1997).

125 See George A Akerlof, The Market for "Lemons": Quality Uncertainty and the Market Mechanism, 84 QUARTERLY JOURNAL OF ECONOMICS 488, 488 (1970).

126 See Leon N. Moses \& Ian Savage, Aviation Deregulation and Safety: Theory and Evidence, 24 J. TRANSP. ECON. POL'Y 171, 172-73 (1990).

127 See id. 
The striking thing about the Internet is that although it has greatly reduced the cost of communications, and that has reduced the cost of investigative reporting to some extent - the existence of WikiLeaks reflects the lower cost of leaking and Bellingcat shows how careful attention to publicly-available Internet data can yield insights into covert activity by states - it has not eliminated those costs in the way that it has all but eliminated the cost of information distribution. Even outfits like Bellingcat that leverage Internet resources to identify new facts require staffs and plenty of time to comb through the data to generate insights. ${ }^{128}$ Thus it may be said that in news the Internet created the perfect environment for ruinous competition. By driving the cost of distribution to zero it drove the marginal cost of publication very low, and reduced the fixed costs associated with printing too, making entry into the market much easier, but it did not eliminate the fixed costs of investigation that are required to maintain product quality in news - meaning to ensure that the quality of information produced is high. ${ }^{129}$ The result is so much competition on price that newspapers have been unable to afford to maintain information quality. ${ }^{130}$ Investigation budgets have been slashed and reporters laid off. ${ }^{131}$ But newspapers have tried to maintain the appearance that they continue to provide coverage with the same level of factual quality as before, leading to the problem of misinformation that currently bedevils the press. ${ }^{132}$

Much scholarly attention has focused on misinformation spread in recent years via social media. ${ }^{133}$ A social media poster might claim election fraud without any basis and, thanks to the reach of social media, this claim may misinform millions of people. ${ }^{134}$ It is useful to think of such individual posters as competing in the same news market as blogs and newspapers. ${ }^{135}$

\footnotetext{
128 See Bellingcat, Annual Report (2019) (showing that Bellingcat spent 354,000 euros, or a third of its budget, on research and investigations in 2019); HAMILTON, supra note 9, at 31112 (noting that advancing "computational journalism" will require investment).

${ }^{129} \mathrm{Cf}$. HAMILTON, supra note 9, at 315.

${ }^{130}$ Cf. id.

131 See Grieco, supra note 8; AlEX JONES, LOSING THE NEWS: THE FUTURE OF THE NEWS THAT FEEDS DEMOCRACY (2009).

${ }^{132}$ Cf. Kavanagh et al., supra note 83, at 119 (suggesting that newspapers maintain the semblance of fact reporting by running personal interest stories as news stories).

${ }^{133}$ See, e.g., Hunt Allcott et al., Trends in the Diffusion of Misinformation on Social Media, 6 RES. POL. 1, 1-2 (2019).

${ }^{134}$ See Jeff Hemsley, Followers Retweet! The Influence of Middle-Level Gatekeepers on the Spread of Political Information on Twitter, 11 POLICY \& INTERNET 280, 297 (2019) (finding that "middle-level" social media influences on Twitter, defined as those having between 1,800 and 2,700 followers, tended to have the greatest "reach, as measured by retweets" in 2014 gubernatorial campaigns).

135 See Kavanagh et al., supra note 83, at 6.
} 
The poster targets a particular slice of the ideological spectrum and reports news. But since a single person cannot invest in uncovering and verifying facts, the quality of the news reported is low and one can expect that over time the poster will lose out in the market to purveyors of more reliable information. But the fact that the poster can nevertheless achieve success in the short run-and while selling a free product - shows how ruinous the competitive pressures faced by newspapers now are.

Of more interest even than this problem, however, is the problem of competition between firms like news websites and legacy newspapers that actually invest in fact development. Unlike in the pre-Internet age, these organizations now have an incentive to try to attract and maintain readers by appealing to ideology rather than fact generation. ${ }^{136}$ Their readership is more ideologically homogenous, so they no longer need fact reporting to appeal to a broad audience, and the proliferation of competitors creates an incentive for them to try to reduce costs by shifting work from high-overhead fact generation to low-overhead opinion writing. ${ }^{137}$ As a result, there has been a proliferation of opinion writing at legacy newspapers, a reduction of ideological diversity in that writing - as each paper now appeals to a smaller swath of the ideological spectrum - and a decline in investment in fact reporting. ${ }^{138}$ The decline in investment in facts is reflected in mass layoffs of journalists, declining public confidence in the news, the closing of overseas news bureaus, and the like. ${ }^{139}$ It has also led to a kind of misinformation more troubling even than the dissemination of falsehoods: the silence of facts not uncovered and reported, because insufficient sums have been invested to uncover the truth. ${ }^{140}$ This problem is most obvious in local news markets in which competition is now so fierce that the markets cannot support any investigative journalism at all. ${ }^{141}$ But it is also taking place at the national level in a less visible form as investment in investigations declines. ${ }^{142}$

The problem is about to get much worse as artificial intelligence algorithms that can write convincing human-readable copy proliferate and

\footnotetext{
136 See JENNifER KaVAnagh \& Michael D. Rich, Truth Decay: An Initial EXPLORATION OF THE DIMINISHING ROLE OF FACTS AND ANALYSIS IN AMERICAN PUBLIC LIFE 95-132 (2018).

137 See id.

${ }^{138}$ See id. at 21-33; Kavanagh et al., supra note 83, at 119; HAMILTON, supra note 9, at 315.

${ }^{139}$ See Grieco, supra note 8; JONES, supra note 131.

140 See Søe, supra note 46, at 323-323 (noting that misinformation can be a product of omission of facts).

${ }^{141}$ See Penelope Muse Abernathy, The Loss of Local News: What It Means for Communities, THE EXPANDING NEWS DESERT, https://www.usnewsdeserts.com/reports/expanding-newsdesert/loss-of-local-news/ (finding that over the past 15 years one in five newspapers has closed and 200 counties in the United States now have no newspaper at all).

${ }^{142}$ See JONES, supra note 131.
} 
decline in price. ${ }^{143}$ Newspapers will soon be able to feed a fact and an ideological tone into an AI and the AI will instantaneously spit out 1200 words of engaging prose reporting the fact from the desired ideological perspective. ${ }^{144}$ Newspapers will be able to tell the AI in effect to "report that such-and-such politician had an affair in a way that pleases moderate conservatives," and the AI will comply. ${ }^{145}$ This will exacerbate the ruinous competition problem because writing is one of the few remaining substantial marginal costs of news article production. Once the fixed costs of fact generation have been sunk into a series of stories, the newspaper must pay someone to "write it up" into an engaging news story, which then can be distributed for a penny or less over the Internet to a vast audience. ${ }^{146}$ Writer AIs, of which GPT-3 is a prototype, will eventually drive that marginal cost of writing up a story to a penny or less. That in turn will enable even more ruinous price competition between newspapers, as the floor on ruinous price competition is marginal cost — even a firm with high fixed costs will exit the market if the cost of running an additional story exceeds the revenue generated from it. ${ }^{147}$ And more ruinous competition in turn will force firms further to reduce investment in fact generation in order to reduce fixed costs and stay solvent. ${ }^{148}$

The Internet's effects on the news show the first law of techno-legal change in action. By reducing the cost of news distribution, the Internet made possible good conduct - a proliferation in the number of ideological viewpoints on offer in the marketplace - but also enabled bad conduct - a reduction in the amount spent on newsgathering and concomitant increase in misinformation. ${ }^{149}$ The second law also applies: the only way to solve this problem is through new legal rules designed to influence the way the new technology is used. The third law tells us that no matter what we do, there will always be more misinformation than we had before. ${ }^{150}$ But hopefully not so much as to make the benefits of the technology, in terms of greater access to diverse viewpoints, pale in comparison.

\footnotetext{
${ }^{143}$ See Kaminska, supra note 17.

144 See id.

145 See id.

146 See Writers and Authors: Occupational Outlook Handbook: : U.S. Bureau of Labor

Statistics, https://www.bls.gov/ooh/media-and-communication/writers-and-authors.htm (last visited Mar. 7, 2021) (stating that the 2019 median hourly rate for writing services was \$30.39).

147 See VARIAN, supra note 47 , at 403.

148 See id.

${ }^{149}$ See HamiLton, supra note 9, at 315.

${ }^{150}$ See supra Section III.A.
} 


\section{B. Regulatory Solutions for Ruinous Competition}

1. Price and Entry Regulation and Direct Regulation in Historical Perspective

Because the problem of misinformation in the news today is fundamentally a problem of ruinous competition-low barriers to entry into news reporting causing prices to fall too low to cover the high fixed costs of fact generation - the history of regulatory responses to ruinous competition gives us a guide to the solution. The problem of ruinous competition arose first in the railroads and other $19^{\text {th }}$-century-era heavy industries, which were characterized by high fixed costs and therefore prone to boom and bust cycles as markets expanded. ${ }^{151}$ Excessive investment in new capacity-new railroad lines, for example - would lead to price wars as firms strove to recoup their investments, and that in turn would bankrupt the industry. ${ }^{152}$ This drove calls during the early- $20^{\text {th }}$ century for a broad-based regime of business licensing that would limit the ability of firms to enter markets when overcapacity threatened. ${ }^{153}$ This culminated in the Great-Depression-era National Industrial Recovery Act, which gave government the temporary power to regulate entry into virtually every market in the United States. ${ }^{154}$ Regulation of entry was closely related to the regulation of price, for if there was already overcapacity in the markets, then the only way to prevent price wars and bankruptcy was to prevent firms from competing for business by lowering prices. Price regulation therefore played an important role as well in regulatory regimes aimed at governing ruinous competition. ${ }^{155}$ Although the NRA eventually went down to constitutional defeat, many other federal

${ }^{151}$ See Michael D Whinston, LeCtures on ANTITRUST ECONOMICS 15-19 (2008); DAVID J. Gerber, LAW AND COMPETITION IN Twentieth CENTURY Europe: Protecting PROMETHEUS 24-27 (2010).

152 See WhInSTON, supra note 151, at 15-19.

${ }^{153}$ See Ellis Wayne HaWley, The New Deal and the Problem of MonOpoly: A Study IN ECONOMIC AMBIVALENCE 36-43 (1966) ("Where the competitive ideal called for the free action of the individual in his own interest, the 'new competition' required that the individual conform to group standards and refrain from engaging in any form of competition that might be destructive to the group as a whole.").

154 See id. at 60-61 (discussing capacity restrictions in NRA codes). The Act gave the President to power to approve "codes of fair competition" proposed by trade associations or other industry groups, which would have the force of law once approved. See Milton Handler, The National Industrial Recovery Act, 19 AMERICAN BAR ASSOCIATION JOURNAL 440, 440-41 (1933). Subject to a few limitations (e.g., the codes could not create monopolies), virtually anything, including market entry or capacity restrictions, could be put into the codes. See id. at 482-83.

155 See HAWLEY, supra note 153, at 57-59. 
and state regulatory regimes aimed at stopping ruinous competition were created around this time, particularly in transportation, including regulation of motor carriers and air travel. ${ }^{156}$

The motivation for stopping ruinous competition was never just the prevention of bankruptcy in key industries, however. Product quality, particularly as it relates to safety, was also an important concern, because firms facing below-cost price competition have an incentive to cut corners. ${ }^{157}$ By using entry restrictions to prevent overcapacity, and price regulation to stop price cutting when overcapacity appeared anyway, it was thought, problems of unfair and deceptive competition-winning by confusing consumers - could be eliminated as well as a happy byproduct. ${ }^{158}$

The regulatory tools of entry restriction and price setting also came around this time to be used to solve a very different problem, that of natural monopoly. ${ }^{159}$ In some industries, like telephone and electric power generation, a single firm comes to dominate the entire market thanks to economies of scale. ${ }^{160}$ Regulation of price is then required to prevent the firm from exercising its monopoly power. ${ }^{161}$ Often regulators sought to use their pricing power to induce the firm to charge socially just prices - to charge higher prices to the rich, and so place a greater burden of covering the firm's costs on the rich, and to charge lower prices to the poor. ${ }^{162}$ The trouble was

156 See Robert L. Rabin, Federal Regulation in Historical Perspective, 38 STAN. L. REV. 1189, 1317 (1986).

157 See HAWLEY, supra note 153, at 60 (noting that some provisions in the NRA's codes of fair competition were meant to "obstruct competition in quality"); Rajiv D. Banker et al., Quality and Competition, 44 MGMT. SCI. 1179, 1191 (1998) (noting that product quality can fall as competition increases if "customer demand exhibits a relatively low quality responsiveness," as would be the case were consumers unable to identify products for which firms have cut corners in maintaining quality).

158 See HAWLEY, supra note 153, at 160; Tobias Gamp \& Daniel Kraehmer, Deception and Competition in Search Markets 3-4 (2018) (noting that as competition increases due, for example, to product standardization, "candid" firms will be driven from the market whereas deceptive firms will not, because deception will make them relatively profitable).

159 See RiCHARD R JOHN, NETWORK NATION: INVENTING AMERICAN TELECOMMUNICATIONS 157-58 (2015) (tracing the origins of the term "natural monopoly" in the rejection by American social scientists of the late 19th century of "antimonopoly as a civic ideal").

160 See CHRISTOPHER DECKER, MODERn ECONOMIC REGULATION: AN INTRODUCTION TO THEORY AND PRACTICE 14-19 (2014).

161 See id. at 19-23.

162 See W. KIP Viscusi ET AL., ECONOMICS OF REGULATION AND ANTITRUST 525-26 (5th ed. 2018) (discussing how telephone pricing by pre-breakup AT\&T contained cross-subsidies); DECKER, supra note 160 , at 34 (discussing the cross-subsidy rationale for regulation generally); J. Gregory Sidak, Abolishing the Letter-Box Monopoly, 1 CRITERION J. INNOVATION 401, 406-8 (2016) (showing how postal service pricing implements crosssubsidies). 
that this pricing could attract entry from smaller firms that could sell only to the rich at slightly lower, but still cost-covering, prices. ${ }^{163}$ To prevent this "cream skimming," regulators therefore also controlled entry into these markets. ${ }^{164}$

Today, scholars tend to associate price and entry regulation with the natural monopoly problem, rather than the problem of ruinous competition, because the deregulatory movement of the 1970s primarily targeted regulation of ruinous competition, leaving only natural monopoly regulation standing today. ${ }^{165}$ Deregulation eliminated regulation of railroads, motor carriers, and airplanes - all industries with both many market participants and relatively high fixed costs in which ruinous competition was once fearedwhile preserving regulation of natural monopoly utilities, including gas and electric power. ${ }^{166}$ Indeed, the plan of the deregulatory movement was to deregulate everything but "bottlenecks," meaning natural monopolies. ${ }^{167}$ Thus regulation of gas pipelines was retained while extraction and downstream power generation were deregulated. ${ }^{168}$ Similarly, California experimented with deregulation of power generation but retained regulation of power transmission, because often it is economical only to run one set of high-tension transmission lines between two points. ${ }^{169}$

The reasons deregulation struck regimes governing ruinous competition were twofold. First, economists have come to believe that markets can handle overcapacity on their own. ${ }^{170}$ As industries mature, incumbents learn to predict industry capacity and plan accordingly. ${ }^{171}$ They also learn to differentiate their products to retain premium customers during price wars. ${ }^{172}$

\footnotetext{
163 See DECKER, supra note 160, at 22-23 (discussing “cream-skimming”); Sidak, supra note 162 , at 406 (discussing "cream-skimming" in the postal context).

164 See DECKER, supra note 160, at 22-23.

165 See Joseph D. Kearney \& Thomas W. Merrill, The Great Transformation of Regulated Industries Law, 98 COLUM. L. REV. 1323, 1326 (1998) ("The role of the agency has been transformed from one of protecting end-users to one of . . overseeing access to and pricing of 'bottleneck' facilities that could be exploited by incumbent firms to stifle competition."). 166 See id. at 1335-40.

167 See id. at 1326.

168 See RiCHARD H. K VIETOR, CONTRIVED COMPETITION: REGULATION AND DEREGULATION IN AMERICA 164 (1996) (noting that the Federal Energy Regulatory Commission "tried to surround 'bottleneck' facilities with open access").

169 See Gary TAYlor Et AL., Market Power AND Market Manipulation in Energy MARKETS FROM THE CALIFORNIA CRISIS TO THE PRESENT (2015).

170 See Reynolds, supra note 117, at 739-44; F. M SCHERER \& DAVID ROSS, INDUSTRIAL MARKET STRUCTURE AND ECONOMIC PERFORMANCE 296-98 (3d ed. 1990).

${ }^{171}$ See SCHERER \& ROSS, supra note 170, at 296-98.

172 See Cristian Huse \& Alessandro V. M. Oliveira, Does Product Differentiation Soften Price Reactions to Entry? Evidence from the Airline Industry, 46 J. TRANSP. ECON. POL'Y 189, 202-3 (2012) (finding that product differentiation in an airline industry reduced the
} 
Second, it turns out that direct regulation of product quality and truth in advertising is effective at preventing firms from cutting corners, even during periods of extreme price competition. ${ }^{173}$ This was demonstrated dramatically in the decades after deregulation of the airlines when the predicted rash of accidents failed to materialize. ${ }^{174}$ It turned out that the FAA's safety regulation regime - the only part of the old airline regulatory system that was retained after deregulation - was sufficient to keep even the planes of budget carriers safe. ${ }^{175}$ But the same was also evident in the success of the Federal Trade Commission, Consumer Product Safety Commission, and other direct regulatory regimes at maintaining product safety in markets throughout the economy despite the absence of generalized price and entry regulation a la the old NRA. ${ }^{176}$

2. Direct Regulation in the News Context Would Violate the First Amendment

This history suggests that the problem of ruinous competition in news should be solved by direct regulation of news quality. Government should create something like a Bureau of Misinformation charged with monitoring news posts for factual accuracy. The current debate over whether the government should continue to provide Internet companies with immunity from suit based on the content of what their users post on websitesimmunity currently guarantee by Section 230 of the Communications Decency $\mathrm{Act}^{177}$ — is related to this question. ${ }^{178}$ Social media posts are a form of news provision - they compete with traditional newspapers - and if the government removes immunity then social media companies will restrict the content that users post, making Section 230, or its absence, a form of

severity of price wars).

173 See, e.g., Milton Handler, False and Misleading Advertising, 39 YALE L.J. 22, 51 (1929) (discussing false advertising rules).

174 See Paul Stephen Dempsey et Al., Airline Deregulation and Laissez-Faire MYThology 304 (1992); VIETOR, supra note 168, at 88.

175 See Fact Sheet - Out Front on Airline Safety: Two Decades of Continuous Evolution, FEDERAL AVIATION ADMINISTRATION, https://www.faa.gov/news/fact_sheets/news_story.cfm?newsId=22975 (last visited Jan. 12, 2021).

176 See David A Moss, When All Else Fails: Government as the Ultimate Risk MANAGER 216-52 (2004) (providing a survey of product liability law); J. Howard Beales, III \& Timothy J. Muris, FTC Consumer Protection at 100: 1970s Redux or Protecting Markets to Protect Consumers?, 83 GEO. WASH. L. REV. 2157, 2159-61 (2015) (surveying the history of the FTC's consumer protection functions).

17747 U.S.C. $\$ 230(\mathrm{c})(1)$ (2018).

178 See Michael A. Cheah, Section 230 and the Twitter Presidency, 115 N.U. L. REV. ONLINE 192, 196-206 (2020). 
regulation of news. ${ }^{179}$ And to the extent that news that is inaccurate in particular is most likely to be actionable absent immunity, Section 230 is a regulation of content accuracy. But the common law causes of action that could be used to challenge content on social media-including defamation and fraud-already apply to Internet news organizations that post their own content and are unlikely to be sufficient to stop the problem of misinformation, including misinformation from lack of investigation, that currently afflicts the news industry. ${ }^{180}$ Partly that is because the First Amendment limits even common law causes of action for defamation and the like, protecting newspapers against defamation lawsuits from public figures unless the paper intentionally lies about them. ${ }^{181}$ But it is also because much misinformation does not create harm to the reputation of a person who is willing to sue and able to prove difficult elements like causation and harm. The New York Times will not face a defamation suit from ISIS based on the falsehoods the paper broadcast in its podcast Caliphate. ${ }^{182}$

To properly address misinformation directly, government would need to regulate newsrooms the way it regulates airplanes: inspecting them to make sure facts are checked, requiring investment in verification operations, and so on. ${ }^{183}$ And here is where the direct regulation of safety in the news context becomes impossible: it would violate the First Amendment's "prior restraints" doctrine. ${ }^{184}$ That doctrine prohibits restrictions on political speech that apply ex ante to block speech before it takes place, such as prepublication expurgations mandated by a board of censors, as opposed to restrictions that merely impose ex post awards of damages as a remedy for breach. ${ }^{185}$ But all direct regulation has an element of prior restraint. The FAA can ground unsafe air fleets; it does not just punish airlines after a crash. ${ }^{186}$ The National Highway Traffic Safety Administration can force a recall of

179 See Shearer \& Matsa, supra note 10 (discussing social media's role as a news source); Cheah, supra note 178, at 198-99 (discussing Section 230 immunity).

180 See Chemerinsky, supra note 2, at 293-94 (listing scenarios in which the First Amendment allows liability for defamation).

${ }^{181}$ See id.

182 See "New York Times" Retracts Core Of Hit Podcast Series "Caliphate" On ISIS, NPR.ORG, $\quad$ https://www.npr.org/2020/12/18/944594193/new-york-times-retracts-hitpodcast-series-caliphate-on-isis-executioner (last visited Jan. 13, 2021).

${ }^{183}$ See Federal Aviation Administration, What is the FAA Safety Assurance System (SAS)? (outlining the FAA's inspection regime).

184 See Ariel L. Bendor \& Michal Tamir, Prior Restraints in the Digital Age, 27 WM. \& MARY BILL RTS. J. 1155, 1158-64 (2019).

185 See id.

186 See Federal Aviation Administration, Airworthiness Certification Overview, https://www.faa.gov/aircraft/air_cert/airworthiness_certification/aw_overview/ (last visited Mar. 9, 2021). 
vehicles; it does not merely impose penalties after unsafe elements in a car lead to injury. ${ }^{187}$

Indeed, it is prior restraint that distinguishes regulation from mere lawmaking. ${ }^{188}$ Without an agency empowered to oversee conduct and prevent dangerous behavior before it happens, regulation is no more than any other law: just a way of issuing threats to firms if they do not behave. ${ }^{189}$ Given that misinformation spreads quickly and that spreaders are often judgment proof, even when they work for major news organizations, due to the poverty of individual journalists, it is unlikely that such threats will stop misinformation. ${ }^{190}$ Actual practice by self-regulating social media organizations shows how integral prior restraints must be to regulation of misinformation. ${ }^{191}$ The suspension of social media accounts-including those of Donald Trump - is one of these companies' main regulatory tools. ${ }^{192}$ Any regime of direct regulation of misinformation predicated solely on ex post remedies is not really regulation, and in any event is unlikely to be effective. ${ }^{193}$

3. Entry Regulation in the Internet Context Would Also Violate the First Amendment

But if direct safety-style regulation of speech to combat misinformation would be unconstitutional, then the strategy of attacking ruinous competition applied by the deregulatory movement is off the table and the alternative of entry and price regulation that the deregulatory movement replaced with direct safety-style regulation is the appropriate response. ${ }^{194}$ Policymakers never rejected entry regulation for being ineffective at maintaining safety, although entry regulation is perhaps less perfect than direct regulation in this

187 See Jerry L. Mashaw \& David L. Harfst, Inside the National Highway Traffic Safety Administration: Legal Determinants of Bureaucratic Organization and Performance, 57 U. CHI. L. REV. 443, 455-58 (1990).

${ }^{188}$ See VISCUSI ET AL., supra note 162, at 435 (defining regulation as government action that "literally restricts the choices of agents").

${ }^{189}$ Cf. id.

190 See U.S. Bureau of Labor Statistics, Reporters, Correspondents, and Broadcast News Analysts: Occupational Outlook Handbook, https://www.bls.gov/ooh/media-andcommunication/reporters-correspondents-and-broadcast-news-analysts.htm (last visited Mar. 9, 2021) (listing the median income of reporters as $\$ 46,270$ per year).

191 See Kate Klonick, The New Governors: The People, Rules, and Processes Governing Online Speech, 131 HARV. L. REV. 1598, 1630-38 (2018).

192 See Kate Conger \& Mike Isaac, Twitter Permanently Bans Trump, Capping Online Revolt, N.Y. TIMES (Jan. 8, 2021), https://www.nytimes.com/2021/01/08/technology/twitter-trumpsuspended.html.

193 See VISCUSI ET AL., supra note 162, at 435.

194 See supra Section IV.B.1. 
regard. ${ }^{195}$ Instead, policymakers rejected entry because they wanted to realize the full benefits of competition - the product variety, the low priceswithout suffering the safety costs of ruinous competition, and they found that this worked when markets were deregulated except for safety. ${ }^{196}$ It follows that when direct safety regulation is not possible, a return to price and entry regulation is reasonable.

By limiting the number of news organizations that can compete in the market, entry regulation in particular would re-create through law the barrier to entry into the news market that once existed naturally before the Internet due to the cost of printing and distributing newspapers to a wide audience. ${ }^{197}$ The recreation of this barrier would reduce competition and increase prices and profits for newspapers, and that would in turn make it easier for newspapers to cover the high fixed costs of investigative journalism. ${ }^{198}$ The reduction in the number of newspapers would also induce newspapers to invest in fact generation rather than opinion reporting because each newspaper would serve a larger and more heterogeneous group of readers. ${ }^{199}$ But it would be a mistake to re-create the old barriers in full, for then the benefits of the Internet would be lost and the market would return to having a small number of centrist publications. ${ }^{200}$ Instead entry regulation would need to strike a middle ground, just as regulation in the transportation sector sought to do during the heyday of price and entry regulation for markets exhibiting ruinous competition, setting entry requirements high enough to prevent ruin but not so high as to stifle beneficial competition. ${ }^{201}$ (Indeed, there were more airlines in America immediately prior to deregulation than there were airlines after it. ${ }^{202}$ )

One approach Congress might take to entry regulation would be to give a regulator - the Federal Communications Commission, say-authority to issue certificates of public necessity as a condition for a firm's entrance into the news media market. The FCC in fact already exercises entry authority with respect to radio and cable broadcasters, including news broadcasters on

\footnotetext{
195 See supra Section IV.B.1.

${ }^{196}$ See VIETOR, supra note 168, at 319-21 (discussing the benefits sought from deregulation); Kearney \& Merrill, supra note 165, at 1327 (noting that deregulation--the rolling back of price and entry regulation--corresponded with growth in social and safety regulation).

${ }^{197}$ Cf. Chemerinsky, supra note 2, at 291.

198 See HAMILTON, supra note 9, at 131.

199 See supra Section III.B.

200 See supra Section III.A.

201 See VIETOR, supra note 168, at 28 (noting in the airline context that the goals of entry regulation included the "avoidance of excess competition" and the "prevention of concentration that might subvert public service").

${ }^{202}$ See id. at 81-83.
} 
those media. ${ }^{203}$ But it is not altogether clear that the FCC would be able to do the same for news organizations on the Internet. The problem is again the First Amendment. Entry regulation, even when not based on content - as is the case with the FCC's regulation of radio and cable entry-is itself a prior restraint on political speech. ${ }^{204}$ Denial of a license is a gag, at least with respect to speech on the Internet. What allows the FCC's entry regulation of radio and cable to avoid conflict with the First Amendment is that the alternative in the case of radio and cable is no speech at all. ${ }^{205}$ Absent limits on broadcasting, broadcasters would flood the market using overlapping channels, leading to electrical interference, degradation in transmission quality, and ultimately the inability to use the media at all. ${ }^{206}$ Thus entry regulation in this case plausibly makes for more speech, rather than less. That would not be true for entry regulation of Internet news. ${ }^{207}$ What makes the Internet conducive to ruinous competition is precisely the fact that so many news organizations can coexist in the medium. ${ }^{208}$

\section{The Postal InTERnet}

\section{A. Dissemination of News as a Postal Goal}

A better way to regulate entry is to follow the model of the post office, rather than that of the FCC, and regulate entry with price. The first national communications network was, of course, the postal network, which connected the country through physical delivery. ${ }^{209}$ Although, by the $1850 \mathrm{~s}$, competition to deliver the news had led newspapers to substitute their own delivery networks - a combination of electronic communication of news or even entire editions to cities, along with regional distribution and "newsboy"

\footnotetext{
203 See Joseph D. Kearney, Will the FCC Go the Way of the ICC Symposium - Part III: A New Role for the FCC and State Agencies in a Competitive Environment, 71 U. COLO. L. REV. 1153, 1170 (2000).

${ }^{204}$ See Glen O. Robinson, The FCC and the First Amendment: Observations on 40 Years of Radio and Television Regulation, 52 MINN. L. REV. 67, 85-93 (1967) (discussing the constitutionality of the FCC's content neutral regulation of entry into telecommunications markets); Valerie C Brannon, Free Speech and the Regulation of Social Media Content, Congressional Research Service Report No. R45650, 46, 28-29 (2019).

205 See Brannon, supra note 204, at 28-29.

${ }^{206}$ See id.

${ }^{207}$ See id.

${ }^{208}$ See id. at 30-32.

${ }^{209}$ See Anuj C. Desai, The Transformation of Statutes into Constitutional Law: How Early Post Office Policy Shaped Modern First Amendment Doctrine, 58 Hastings L.J. 671, 68195 (2007); Richard R. JoHn, SPREAding THE NEWS: THE AMERICAN Postal System FRom FRANKLIN TO MORSE 25-64 (1995).
} 
networks - for the mail, the mail was for half a century the primary means by which a newspaper reached an audience beyond the city in which the paper was headquartered. ${ }^{210}$

The use of the mail to deliver newspapers was not an afterthought; it was the reason the Framers provided for a postal service. ${ }^{211}$ Prior to the revolution, the crown conferred the right to deliver mail as a monopoly on private businessmen, preventing newspapers from creating their own distribution networks. ${ }^{212}$ The businessmen used the monopoly in effect to tax away newspaper profits through the charging of above-cost prices. One of the goals of the revolution that followed was free speech, both in the sense of libertine and in the sense of gratuitous. ${ }^{213}$ Accordingly, the creation of a taxpayer-funded postal service that would allow newspapers to distribute the news at no cost through the mail was an early priority for the new Republic. ${ }^{214}$ It was wildly successful. Newspapers flourished and the $19^{\text {th }}$ century American press became the envy of the world. ${ }^{215}$ No less a figure than Alexis de Tocqueville remarked that a back woodsman in Kentucky was better informed than a suburban Parisian because of cheap and speedy access to the news via the mail. ${ }^{216}$

Newspapers still faced substantial printing costs during this period, so distribution costs were not as low as they have now become in the Internet age, and of course distribution was much slower. ${ }^{217}$ Indeed, it was that slowness that eventually pushed costs up for newspapers, reducing their numbers to the low levels (in the national market) that existed on the eve of the Internet. ${ }^{218}$ Competition between papers, stiffened by competition from electronic media-first the telegraph, then radio and television-caused newspapers eventually to bypass the postal system and build out their own

210 See Paul Starr, The Creation of the Media: Political Origins of Modern COMMUNICATIONS 174-75 (2006); Santiago Kraiselburd, The Evolution of Real Newsboy Contracts in the US, SSRN SCHOLARLY PAPER ID 1011204 9-11 (Jan. 20, 2006), https://papers.ssrn.com/abstract=1011204.

${ }^{211}$ See Desai, supra note 209, at 690-95.

212 See id. at 678-81.

${ }^{213}$ See id. at 681-90.

${ }^{214}$ See id. at 690-95.

215 See JoHN, supra note 209, at 1-2.

216 See id.

217 See Patrick Hendriks, The Economic Fundamentals of Newspaper Publishing, in NewsPapers: A Lost CAUSE? STRATEGIC MANAGEMENT OF NEWSPAPER FIRMS IN THE United States AND THE Netherlands 15, 19-20, 24 (Patrick Hendriks ed., 1999) (discussing newspaper printing costs). Costs did, however, fall. STARR, supra note 210, at 124 (discussing the rise of the "penny press" in mid-19th century America).

218 See Robert G. Picard, The Economics of the Daily Newspaper Industry, in MEDIA ECONOMICS: THEORY AND PRACTICE 109, 110 (Alison Alexander et al. eds., 2003). 
physical distribution systems designed to get the news across the country overnight. ${ }^{219}$ This greatly increased the cost of competing in national news markets. $^{220}$ This increase in cost is also attributable to the failure of government to update, for improvements in technology and capacity, the revolution-era vision of promoting the news by subsidizing distribution. ${ }^{221}$ The Postal Service could itself have built out the overnight delivery networks used by the press, in order to continue to serve as the backbone for ever more timely distribution of news. ${ }^{222}$ Perhaps the problem was that doing so would have required vertical integration by the government into the printing of the news, as the printing of papers at regional centers was a core part of that distribution model, and that would have offended free-speech sensibilities. ${ }^{223}$ But there would have been no real conflict with the First Amendment, for newspapers would have remained free to print and distribute their editions on their own. ${ }^{224}$

A consequence of the failure of the postal system to maintain the subsidy as newspapers strove for faster distribution is that the character of the news industry changed along the lines suggested by the monopolistic competition model. ${ }^{225}$ News in the $19^{\text {th }}$ century was diverse, ideological, opinionated, and often unreliable. ${ }^{226}$ But as distribution costs mounted, the news business became progressively more consolidated and fact-based, with the ideal of objectivity - the instantiation in the culture of the news business of the notion that centrism and fact-based reporting are necessary for competitive

\footnotetext{
219 See STARR, supra note 210, at 174-75, 179 (noting that the rise of the telegraph helped lead to the creation of evening papers); MENAHEM BLONDHEIM, NEWS OVER THE WIRES: THE TElegraph AND THE Flow OF PUBliC INFORMATION IN AMERICA, 1844-1897 27-29 (1994) (discussing mid-19th century competition in the speed of news delivery).

${ }^{220}$ See BLONDHEIM, supra note 219, at 19 (discussing some of the costs associated with 19th century competition for timeliness in news).

${ }^{221}$ See Desai, supra note 209, at 681-90.

${ }^{222}$ Cf. id.

${ }^{223}$ See STARR, supra note 210, at 184-85 (noting that the Associated Press, which transmitted news via telegraph, supplied most of the news printed in small-town newspapers in the mid19th century). The British Post Office nationalized the telegraph during this period, which helped keep it out of private monopoly hands and made it easier for smaller newspapers to remain competitive, but did not provide the last-mile distribution of electronicallytransmitted news that was provided by newspapers and had been provided by postal services when the news moved exclusively through the mails. See id. at 183 . That concerns about free speech, rather than just a lack of vision, was the cause of the failure of the Postal Service to keep up with technological change, is admittedly, debatable. See id. at 267-68 (pointing out that free speech did not "become a cause" until the 20th century).

${ }^{224} C f$. STARR, supra note 210, at 183 (discussing the British Post Office's nationalization of the telegraph and its supply of low-cost telegraph services to independent newspapers).

${ }^{225}$ See supra Part III.

${ }^{226}$ See STARR, supra note 210, at 254-59.
} 
success-emerging as the central tenet of journalism in the mid- $20^{\text {th }}$ century. 227

\section{B. Using Postage to Regulate the Internet News Market}

The postal system was, then, from its very inception, an attempt by government to influence entry into the market for news through the price of distribution, albeit one that became increasingly ineffective as the government failed to update the system to take account of technological advance. ${ }^{228}$ And the goal of regulating entry through price was to promote the timely dissemination of accurate information to Americans. ${ }^{229}$ Operating against a technological backdrop of extreme constraint, in which national communication was impossible without the technological innovation that was the mail, the early post office sought to achieve that goal by promoting entry into the market through reductions in the price of distributionsubsidizing entry using tax revenues. ${ }^{230}$ But today, when the Postal Service finds itself operating against the backdrop of the opposite technological extreme - a near-zero cost of distribution - it is entirely consistent with the goal of promoting dissemination of accurate information for the Postal Service to take the opposite approach of discouraging entry into the market by increasing the price of distribution. ${ }^{231}$ If the Postal Service were somehow able to assert control over the Internet infrastructure used today to disseminate the news, it could raise the cost of distribution of news enough to put an end to ruinous competition without raising prices so high as to wipe out all of the benefits of low-cost communication afforded by that infrastructure.

The Postal Service is already in the business of charging prices that are not strictly tethered to costs, because the Postal Service is itself a business characterized by high fixed costs-delivering an additional letter costs the Postal Service very little but maintaining the network of distribution centers and mail carriers required to deliver any amount of mail costs a lot-and fixed costs create pricing flexibility. ${ }^{232}$ An implication of the Postal Service's large fixed costs is that the Postal Service has a large amount of costs that are

\footnotetext{
227 See SCHUDSON, supra note 75, at 121-59 (tracing the rise of the ideal of objectivity in journalism); Picard, supra note 218, at 110 (discussing newspaper consolidation).

228 See supra Section V.A.

${ }^{229}$ See Desai, supra note 209, at 681-90

${ }^{230}$ See Desai, supra note 209, at 690-95.

${ }^{231}$ See Wallsten, supra note 43 (charting declines in communication costs).

${ }^{232}$ See United States Postal Service Office of Inspector General, A Closer Look at Postal Labor Costs 3 (Dec. 2, 2019), https://www.uspsoig.gov/document/closer-look-postal-laborcosts (providing an overview of the Postal Service budget in 2018) .
} 
not associated with the delivery of any particular piece of mail, but instead must be charged in arbitrary fashion to customers. ${ }^{233}$ In order to cover fixed costs, the Postal Service must apportion those costs across its customers, deciding whether, for example, senders of holiday cards or buyers of passport photos should pay them. ${ }^{234}$ But each decision that the Postal Service makes about how to price to cover costs has an effect on the behavior of the Postal Service's customers. Those that face higher prices use the system less than those who face lower prices. ${ }^{235}$ Thus the Postal Service is necessarily already in the business of using prices both to encourage and restrict entry into the postal distribution system. If the Postal Service were properly empowered to charge for access to the Internet, it could then apply the same pricing techniques to regulate access to the Internet.

The advantage of the use of price to regulate access, rather than direct licensing, is that price is not a prior restraint. ${ }^{236}$ To be sure, price does prevent those who cannot afford it from gaining access, and therefore tends to block access based on wealth, but it is sufficiently facially neutral - anyone who can afford the price gains access - that it does not count as an ex ante restriction on speech in the eyes of the Supreme Court. ${ }^{237}$ Indeed, the neutrality of price is particularly pronounced in the news context, because price-based restrictions are unlikely to favor any one part of the ideological spectrum, even that associated with the nation's wealthy. Each newspaper is ultimately only as wealthy as its readership, and a slave to its readership's preferences. ${ }^{238}$ As the monopolistic competition model shows, news organizations will tend to spread out over the ideological spectrum as they compete to maximize readership. ${ }^{239}$ It follows that the firms that will be best able to pay the distribution prices that the Postal Service charges will be those that will most effectively spread out across the ideological spectrum while

\footnotetext{
${ }^{233}$ See id. at 2-3 (providing an estimate of average Postal Service labor cost per unit of mail volume of between $\$ 1$ and $\$ 4)$.

${ }^{234}$ See 39 U.S.C. $§ 3622(b)(8)$ (requiring that such allocation be "just and reasonable").

${ }^{235}$ See VISCUSI ET AL., supra note 162, at 523-25 (discussing these effects in the context of Ramsey pricing).

${ }^{236}$ See supra Section IV.B.2.

${ }^{237}$ See Elizabeth Clarke, Must the Government Waive Public Forum User Fees for Indigent Speakers Comments, 83 U. CHI. L. REV. 2027, 2032 (2016).

${ }^{238} C f$. Prior, supra note 5, at 103 (noting that in more fragmented media markets newspapers serve readers' tastes); Anthony Downs, An Economic Theory of Political Action in $a$ Democracy, 65 J. PoL. ECON. 135, 137 (1957) ("[P]olitical parties in a democracy formulate policy strictly as a means of gaining votes. They do not seek to gain office in order to carry out certain preconceived policies or to serve any particular interest groups; rather they formulate policies and serve interest groups in order to gain office.").

${ }^{239}$ See supra Section III.B.
} 
they are in the market. ${ }^{240}$ Firms that fail to diversify sufficiently will drop out of the market, unable to pay for distribution, ensuring that Postal Service pricing will limit entry without biasing it in favor of any one ideological position. ${ }^{241}$ Under an entry licensing scheme, by contrast, the FCC would have a harder time maintaining ideological diversity because the FCC would not be able to draw on a market test in identifying the firms most likely to compete effectively in ideological diversification. ${ }^{242}$

The Postal Service could deal with the problem of individual social media posters (as well as corporate websites, which effectively communicate a message whenever they are visited), by employing a pricing scheme based on the number of people to whom a message is actively delivered in a given unit of time. Distribution to a small audience - say 50, 100, or even 1000over the course of a day might be free, meaning that anyone could send a mass email with a thousand recipients, or tweet to 1000 followers, or post a post on Facebook that appears in the feeds of a thousand friends, all without paying postage. Thus family or town-size distribution-the sort of distribution that might be had before the Internet by a speech to a large auditorium-would be free. But the Postal Service would charge for distribution above that number, which would mean charging for the kind of distribution that, before the Internet, was only possible via newspapers. The postage could be a per-recipient charge. Or it might be a bulk rate, graduated by orders of magnitude: a certain fee for 10,000 recipients, a higher fee for 100,000 recipients, and so on. The fee structure could be calibrated over time based on the market outcomes it produces, measured ultimately in the speed and accuracy with which news is reported, as well as the level of investment by private newspapers in the generation of news. ${ }^{243}$

The overall effect of this pricing scheme would be to keep small individual posters and organizations that are not in the business of news reporting, and therefore lack a revenue stream and the incentive to invest in fact discovery and verification, out of the national news market for lack of funds to pay Internet postage. That does not mean that the great democratizing benefits of the Internet would be lost. ${ }^{244}$ Before the Internet,

\footnotetext{
${ }^{240}$ See supra Section III.B.

${ }^{241}$ See supra Section III.B.

${ }^{242}$ And of course any attempt be the FCC to regulate entry based on ideological position would likely violate the First Amendment. See supra Section IV.B.3.

243 Cf. Steven Orla Kimbrough, Agents, Games, and Evolution: Strategies AT WORK AND PLAY 185-98 (2011) (showing, via a simply model, how private firms calibrate their prices to maximize value).

244 See, e.g., American Civil Liberties Union v. Reno, 929 F. Supp. 824, 881 (Dist. Court 1996) ("The plaintiffs in these actions correctly describe the 'democratizing' effects of Internet communication: individual citizens of limited means can speak to a worldwide
} 
few speakers could reach an audience of more than half a dozen peopletheir family - for free while lounging in their pajamas on a Sunday morning, whereas under this scheme a speaker would be able to reach a thousand people any time for free, something that might otherwise have been available to the speaker before the Internet only once in a lifetime during a special event. ${ }^{245}$ But it would mean that people with little ability to generate reliable facts would be able to reach the nation only indirectly through a larger gatekeeper organization, such as the freelance pages of a commerciallyviable newspaper, having the ability and incentive to verify facts. Pricing should be structured to ensure that there are more than just the two national newspapers that existed before the Internet, ensuring that the ability of the Internet to make possible a broader diversity of gatekeepers than existed in the past would be preserved as well. ${ }^{246}$

\section{Postage for Posting, Rather Than for Internet Access}

But how to enable the Postal Service to charge Internet postage? One way that seems most analogous to what the Postal Service does today would be to put the Postal Service in charge of the Internet's distribution infrastructure, the Internet pipes today owned and operated by the nation's telecom companies. ${ }^{247}$ That is a non-starter, however, if only because control over the Internet's pipes would not be necessary for the Postal Service to achieve its goals. When distribution was expensive, postal ownership of the distribution infrastructure was essential to promoting the spread of accurate information, because no one else could afford to build the infrastructure and subsidize access to it. ${ }^{248}$ Now that the barrier to the spread of accurate information is too much distribution provided at too low a price by the private sector, postal ownership of the distribution infrastructure is not required to solve the problem: only the power to raise distribution prices is needed. ${ }^{249}$ Thus the nature of the problem today makes it possible to abstract the Postal Service away from distribution infrastructure and treat it exclusively as a creature of its broader, core mission of ensuring that Americans get the best information

audience on issues of concern to them.").

${ }^{245}$ Cf. id.

${ }^{246} C f$. Picard, supra note 218, at 110 (describing newspaper concentration immediately before the Internet).

${ }^{247}$ See Markus Muller, Who Owns the Internet - Ownership as a Legal Basis for American Control of the Internet, 15 FORDHAM INTELL. PROP. MEDIA \& ENT. L.J. 709, 730 (20042005).

248 See Desai, supra note 209, at 681-90.

${ }^{249}$ See supra Section IV.A. 
fast. $^{250}$

A focus on that core mission also makes clear that control over the price of Internet access, which would be the natural lever for the Postal Service to pull were the Postal Service to take control over the Internet's pipes, would not be properly tailored anyway to the achievement of the Postal Service's goals. ${ }^{251}$ For the Internet's pipes are more akin to the roads over which Postal Service trucks trundle than to the trucks themselves and the postal network that delivers the mail. Internet access makes it possible not just to disseminate information to the public at large - the function of news reporting — but also to make purchases, organize book clubs, engage in private conversations, and the like. That is, Internet access enables commerce of all sorts, not just the distribution of news. ${ }^{252}$ Raising the price of Internet access would therefore curtail commerce generally, not just commerce in news. ${ }^{253}$ But what the physical Postal Service sells is news distribution, not access to commerce generally (although much non-news commercial business does piggyback on this news distribution channel-you can buy clothes via mail order, for example), and so the price that the Postal Service should regulate on the Internet is the price of news distribution. That price today is set to zero; no one pays per recipient to send email or post on social media.

Given the profusion of applications that can be used to communicate news over the Internet to a mass audience-everything from email applications, to chat applications, to Facebook, to Twitter - it might appear technically difficult for a government authority to regulate them all. ${ }^{254}$ But in fact the same flexibility of programming that makes possible the profusion of services on the Internet also would make it easy as a technical matter for the Postal Service to police Internet services. A rule requiring that every Internet communication protocol include a function that reports the number of recipients of a particular missive to a central authority - no reporting of the identity of recipients required-would ensure that all Internet-based news distribution could be taken into account by the Postal Service in charging postage. $^{255}$ (The Postal Service already has the general authority to issue

\footnotetext{
${ }^{250}$ See supra Section V.A.

${ }^{251}$ See Shane Greenstein, The Basic Economics of Internet Infrastructure, 34 THE JOURNAL OF ECONOMIC PERSPECTIVES 192, 205-9 (2020) (discussing the pricing of Internet infrastructure).

252 See Rachel Nuwer, What If the Internet Stopped Working for a Day?, https://www.bbc.com/future/article/20170207-what-if-the-internet-stopped-for-a-day (last visited Mar. 10, 2021).

${ }^{253}$ See id.

${ }^{254}$ See Shearer \& Matsa, supra note 10 (discussing a variety of social media platforms that transmit news).

255 See Anat Hovav et al., A Model of Internet Standards Adoption: The Case of IPv6, 14
} 
regulations that advance its core mission, so it could issue such a rule. ${ }^{256}$ ) The fact that economies of scale have already centralized most Internet communications within a few servers - Gmail for email, and Facebook and Twitter for social media-will make a proper accounting even easier to execute. ${ }^{257}$

\section{Letter-Box Monopoly as Preexisting Authority to Charge Internet Postage}

But how, then, to get the Postal Service the power to set prices for the distribution of news over the Internet? The answer is that the Postal Service already has the power, so long as the Postal Service creatively interprets "letter-box" in some special statutory language to include all virtual mailboxes - the receipt of missives of all forms over the Internet, rather than just physical mailboxes at physical addresses. Federal law currently prohibits

deposit[ing] any mailable matter . . . on which no postage has been paid, in any letter-box . . . accepted by the Postal Service for the ... delivery of mail matter ... with intent to avoid payment of lawful postage thereon ... . ${ }^{258}$

The law, which lists "statements of accounts, circulars, [and] sale bills" as examples of "mailable matter," was clearly written with paper mail and physical mailboxes in mind. ${ }^{259}$ But the Postal Clause of the Constitution provides Congress with only the power to "establish Post Offices and post Roads," but that has not stopped Congress from conferring a monopoly on the delivery of first-class mail on the Postal Service, so clearly what drafters had in mind is not the sine qua non of statutory interpretation, at least in the postal context. ${ }^{260}$ And the language of the statute and the postal laws more broadly are capacious enough to authorize postal control over the virtual letter-box, as will become clear shortly.

Congress has broadly prohibited anyone from delivering "letters," a term that Congress allows the Postal Service itself to define. ${ }^{261}$ But that prohibition

INFORMATION SYSTEMS JOURNAL 265, 265-66 (2004) (describing how Internet standards function).

25639 U.S.C. $\S 401(1)$ (2018).

${ }^{257}$ See H. B. Acharya et al., Few Throats to Choke: On the Current Structure of the Internet, 2017 IEEE 42nd Conference on Local Computer Networks (LCN) 339, 339 (2017).

25818 U.S.C. $\$ 1725$ (2018).

25918 U.S.C. $\$ 1725$ (2018).

${ }^{260}$ U.S. Const. art. I, § 8, cl. 7; Ex Parte Jackson, 96 U.S. 727, 732 (1877).

26118 U.S.C. $§ 1694$ (2018). 
includes an exception for self-delivery of letters-technically, letters conveyed "by private hands without compensation." ${ }^{262}$ In the 1930s, Congress worried that utility companies were taking advantage of the exception to deliver their own montly bills to customers and thereby deprive the Postal Service of a revenue stream. ${ }^{263}$ In response, Congress expanded the postal monopoly to prohibit not just the act of delivering a letter in competition with the Postal Service, but, through the statute excerpted above, the act of putting letters (and indeed any "mailable matter") in mailboxes used by the Postal Service, creating what has come to be called the Postal Service's "letter-box monopoly."264 The Supreme Court has said that the purpose of this monopoly, along with the broader prohibition on running a competing letter delivery service, is to enable the Postal Service to provide "universal service," understood to include mail delivery to rural areas at reasonable rates far below the high actual cost of such service. ${ }^{265}$ Absent the Postal Service's monopolies, commercial carriers would skim the cream. ${ }^{266}$ They would compete with the Postal Service on the profitable urban roots, leaving the Postal Service with no money left over to fund unprofitable rural routes. $^{267}$

The anti-cream-skimming rationale for the letter-box monopoly is concerned with keeping the price of postage low, to the end of promoting the broad dissemination of accurate news. In the 1980s, when the Supreme Court articulated this rationale, as today, low postage prices are perhaps still necessary for news transmission in some rural areas not yet served by cellular or radio broadcasts. ${ }^{268}$ But for most Americans, the same broad rationale of promoting the distribution of accurate information would support the use of the Postal Service's letter-box monopoly to do the opposite: to raise prices to the end of stopping ruinous competition in the spread of news on the Internet. If the Postal Service, with the assent of the courts, construes all Internet-based messaging programs as "letter-boxes," then the letter-box monopoly explicitly prohibits the delivery of any message via these programs without

\footnotetext{
26218 U.S.C. $\$ 1696$ (2018).

263 See Sidak, supra note 162, at 411.

${ }^{264}$ See id. at 411-12.

265 See Postal Service v. Council of Greenburgh Civic Assns., 453 U.S. 114, 122 (1981); Air Courier Conference of America v. American Postal Workers Union, 498 U.S. 517, 519 (1991); Sidak, supra note 162, at 406-7.

266 See Sidak, supra note 162, at 406-7.

267 See id.

${ }^{268}$ See Postal Service v. Council of Greenburgh Civic Assns., 453 U.S. at 122; Demographics of Internet and Home Broadband Usage in the United States, PEW RESEARCH CENTER: INTERNET, SCIENCE \& TECH, https://www.pewresearch.org/internet/fact-sheet/internetbroadband/.
} 
postage, thereby enabling the Postal Service to charge a price for any message delivered over the Internet. The Postal Service could then use the power to charge for postage to create a graduated fee structure for the sending of Internet messages, much the way today the Postal Service charges different rates for individual letters than the Postal Service charges for bulk mail sent by advertisers. ${ }^{269}$

Redefining "letter-box" to include all Internet messaging systems would not be hard because the Postal Service itself has been given authority by Congress to define the meaning of "letter," and could issue new regulations defining the word to include electronic messages, causing "letter-box" in turn to refer to programs for the receipt of electronic correspondence, and the letter-box monopoly in turn to prohibit the receipt of electronic messages without payment of the Postal Service's fees. ${ }^{270}$ The "mailable matter" not allowed in the letter-box without postage would then be electronic messages, for letters are "mailable matter" and letters would now be understood to include electronic missives.

Why not rely upon the monopoly on the act of delivering letters also provided the Postal Service in order to charge for electronic missives ? ${ }^{271}$ The answer is that the Postal Service would not provide an electronic message delivery service under my proposed scheme. The Postal Service would not provide email services or social media services (though some have proposed that it should) and so the Postal Service could hardly use a monopoly on the act of delivery to charge high prices for that service. ${ }^{272}$ The elegance of the letter-box approach is that it would allow the Postal Service to achieve its goal of using prices to structure the news market without putting the Postal Service in the position of having to engage in actual delivery of the news, thereby allowing the Postal Service to sidestep claims of critics that the Postal Service's monopoly provision of services tends to make those services inefficient. ${ }^{273}$ By using the letter-box monopoly to set prices while allowing the private sector to continue to supply Internet messaging services, this plan

\footnotetext{
${ }^{269}$ The Postal Service has the authority to define different classes of mail and charge different rates of postage for them. 39 U.S.C. $\$ 404$ (b) ("[T]he Governors are authorized to establish reasonable and equitable classes of mail and reasonable and equitable rates of postage and fees ....").

${ }^{270}$ See Sidak, supra note 162, at 408 ("[T] he monopolist has had the power largely to define the scope of its own monopoly."). For the Postal Service's current definition of "letter," see 39 C.F.R. § 310.1(a).

${ }^{271}$ See 18 U.S.C. $\$ 1694$ (2018).

272 See Arthur S. Hayes, The USPS as an OSP: A Remedy for Users' Online Privacy Concerns, 19 COMMC'N L. POL'Y 465, 480-90 (2014).

273 See generally J. Gregory SidAK, PROtecting COMPETITION FROM THE PostaL MONOPOLY (1996).
} 
should have no effect on efficiency. ${ }^{274}$ Indeed, by eliminating ruinous competition without returning the market to the pre-Internet duopoly, the plan should increase efficiency. ${ }^{275}$

Equally important, not providing electronic delivery services is also a prerequisite for the Postal Service to reinterpret "letter" to include electronic missives. The Postal Service is prohibited by law from issuing any further regulations that would "preclude competition or establish the terms of competition," but not if "the Postal Service demonstrates that the regulation does not create an unfair competitive advantage for itself." 276 If the Postal Service does not itself distribute news over the Internet, its use of the letterbox monopoly to charge Internet postage would not give it a competitive advantage in any market, and so the Postal Service would be free to expand the scope of the letter-box monopoly to include virtual letter-boxes.

The proposed separation of pricing authority from service provision may appear novel, but the language of the postal statutes can be read to permit it. Congress included among the Postal Service's enumerated powers the power "to prescribe ... the amount of postage and the manner in which it is to be paid," and did not explicitly tie this power to the other enumerated powers, such as the power to "provide for the ... delivery ... of mail." ${ }^{277}$ The pricing provisions of the statute also do not require that pricing equal cost of service, a requirement that could not be met were the Postal Service to charge for electronic messages without delivering them; the provisions require only that pricing be "reasonable." ${ }^{278}$ High pricing designed to stop ruinous competition and maintain information integrity is reasonable. The law does require that each class of mail bear all costs attributable to it, but does not prohibit abovecost pricing - thus the statute does no more than prohibit pricing below attributable costs. ${ }^{279}$ This would not prevent the Postal Service from charging any price its wishes for electronic missives, as there would be no attributable costs of service under this proposal because the Postal Service would sell no electronic message services.

\footnotetext{
274 To be sure, there will be the sort of allocative inefficiency that arises whenever a poor proxy for desire, such as price, is issued to determine access to a resource. There will be some people who will be priced out of the market even though they place such a high personal value on large-scale Internet speech that allowing them to reach a large audience would increase aggregate welfare, even after taking any social costs associated with the falsehoods they spout into account. See Ramsi A. Woodcock, The Economics of Shortages, LAW \& POL. ECON. BLOG (Jun. 2, 2020), https://lpeblog.org/2020/06/02/the-economics-ofshortages/.

${ }^{275}$ See supra Section V.B.

27639 U.S.C. § 404a (2018).

27739 U.S.C. $\$$ 404(a) (2018).

27839 U.S.C. $\S 3622($ b)(8) (2018).

27939 U.S.C. § 3622(c )(2) (2018).
} 
The statute contemplates the creation by the Postal Service of different classes of mail and uniform pricing for each class. Thus, according to the statute, first-class mail should be charged at the same rate to all Americans, second class at the same rate, and so on. ${ }^{280}$ This would seem to prohibit the charging of lower prices for those who send fewer messages, and for this reason the Postal Service gives advertisers bulk rates today only by requiring that they presort the mail for the Postal Service, which allows the Postal Service to rely on a provision that permits pricing to take "the degree of preparation of the mail" into account. ${ }^{281}$ But the statute also permits pricing in accordance with "the policies [of the postal law] as well as such other factors as the Commission determines appropriate." 282

One advantage of relying on the letter-box monopoly to regulate the price of Internet speech is that the letter-box monopoly has already withstood challenge on First Amendment grounds. Although the challenge was to the monopoly in its physical mailbox form, the rationale applied by the Court to defend the physical monopoly against the First Amendment applies with equal force to the virtual monopoly. In Postal Service v. Council of Greenburgh Civic Assns., the court rejected a First Amendment challenge to the letter-box monopoly because, according to the Court, the letter-box is not a public forum, and is instead more akin to a military base, in which government can regulate speech. ${ }^{283}$ The Court observed that nothing prevents those who wish to communicate without paying for postage from depositing missives elsewhere, whether on a doorhandle or in a non-postal mailbox. ${ }^{284}$

Extension of the letter-box monopoly to include receipt of all Internetbased missives does not change this calculus. In 1981, when Greenburgh was decided, there was no Internet, and the only alternative to placing a communication in a physical mailbox was to put the communication on a doorhandle or elsewhere on the recipient's property. ${ }^{285}$ That would still be true after the extension of the letter-box monopoly to virtual mailboxes: those wishing to communicate without paying for postage would still be able to hand-deliver their communications to a non-postal physical receptacle. Indeed, there would be more opportunity for alternative speech available today under an expanded virtual letter-box monopoly than there was when Greenburgh was decided, because the Postal Service would not use the monopoly to charge for communications that have a small volume by Internet

\footnotetext{
28039 U.S.C. $\$ 404(c)(2018)$.

28139 U.S.C. $\$ 3622(\mathrm{c})(5)(2018)$.

28239 U.S.C. $\$ 3622$ (c )(14) (2018).

${ }^{283}$ See Postal Service v. Council of Greenburgh Civic Assns., 453 U.S. 114, 129 (1981).

${ }^{284}$ See id.

${ }^{285}$ See id.
} 
standards - say, up to 1000 recipients - but an unimaginably large volume by 1981 standards. ${ }^{286}$

Here we see the second law of techno-legal change in action. ${ }^{287}$ The removal of technical barriers - the advent of the Internet and the consequent removal of barriers to speech-requires the replacement of some of those barriers with legal barriers - here a letter-box monopoly that would limit the ability freely to exercise the new power, but only in some cases (when the number of recipients is large) and then only by requiring payment, rather than banning the speech outright. In order for the second law to function-for legal restrictions to make up for the bad consequences of the freedom bestowed by technology - it is necessary for the law in fact to act. Here that means that the First Amendment cannot be so enlarged in response to technological change as to prevent any regulation of the new technology.

In the 1997 case Reno v. American Civil Liberties Union, the Court seemed, however, to be heading in the direction of expanding the reach of the First Amendment so broadly as to prevent regulation of the new technology. ${ }^{288}$ In that case, the Court held that the Internet is a public forum akin to streets and public squares in which the First Amendment prohibits almost all government regulation of speech. ${ }^{289}$ As applied to a virtual letterbox monopoly, that ruling conflicts with Greenburgh, which held that the letter-box is not a public forum. ${ }^{290}$ It is not clear whether the letter-box character of a virtual letter-box monopoly supersedes the virtual aspect of a virtual letter-box monopoly, in which case Greenburgh would control and there would be no First Amendment protection for the virtual letter-box, or vice versa, in which case Reno would control and the virtual letter-box monopoly would constitute a potentially unconstitutional regulation of public speech. $^{291}$

But even if the Internet is a public forum, a virtual letter-box monopoly is likely to survive First Amendment scrutiny. For when the Court ruled in Reno that the Internet was a public forum, it was the late 1990s and the Internet was, as the Court itself recognized, still in its infancy. ${ }^{292}$ The problem of ruinous competition in the news had not yet appeared. When the Court revisits the issue, it is likely to treat the Internet more like broadcast radio or television than like a public park, allowing regulation of speech where doing

\footnotetext{
286 See supra Section V.B.

${ }^{287}$ See supra Section II.

288 Reno v. American Civil Liberties Union, 521 U.S. 844 (1997).

${ }^{289}$ See id. at 868-69.

${ }^{290}$ See Postal Service v. Council of Greenburgh Civic Assns., 453 U.S. at 129.

${ }^{291}$ Compare Reno v. American Civil Liberties Union, 521 U.S. at 868-69; with Postal Service v. Council of Greenburgh Civic Assns., 453 U.S. at 129.

${ }^{292}$ See Reno v. American Civil Liberties Union, 521 U.S. at 868-69.
} 
so promotes the free flow of accurate information rather than restraining it. ${ }^{293}$ The Court has long upheld licensing restrictions for broadcast spectrum because the Court recognizes that a spectrum marred by interfering signals impedes accurate speech instead of promoting it. ${ }^{294}$ Similarly, a virtual letterbox monopoly that reduces ruinous competition promotes accurate speech and should survive scrutiny.

No matter how strictly the Postal Service wields the letter-box monopoly, however, the third law of techno-legal change will still apply. No matter how little protection the First Amendment provides Internet speech, or how oppressive the Postal Service's wielding of the letter-box monopoly, the invention of the Internet will still lead to a net increase in freedom. The Postal Service will be unable to identify all Internet communications and less able still to enforce against them. So there will always be too much competition, and therefore too much misinformation, in Internet news.

\section{CONCLUSION}

The cause of the current misinformation epidemic is not monopolization of advertising markets by Big Tech, but rather ruinous competition in news reporting made possible by the low cost of communication on the Internet. That has not only made it difficult for newspapers to cover the costs of investigations and fact verification, but also made fact reporting less important to success in a fragmenting news market in which papers no longer need fact reporting to appeal to broad, ideologically-diverse readerships. With less investment in facts comes misinformation. The solution is to use the law to bring back some, but not all, of the costs of communication that the Internet removed. By reinterpreting its statutory "letter-box" monopoly to apply to virtual letter-boxes - all programs that receive messages over the Internet - the Postal Service could charge for bulk delivery of Internet messages, ensuring that only news organizations that have enough resources to invest in investigation and fact verification are able to use the Internet to reach a national audience.

The three laws of techno-legal change apply here. The first law is that technology removes restrictions: here the Internet removes technological restrictions on mass speech by reducing the cost of communication. But some of the restrictions are good, and the second law holds that legal rules are required to put those restrictions back into place, here by restoring part of the cost of communication. The third law teaches that while legal rules can put restrictions back into place, legal rules will never restore them as completely

\footnotetext{
${ }^{293}$ See supra Section IV.B.3.

${ }^{294}$ See Brannon, supra note 204, at 32.
} 
as they existed before technology tore them down. Raising the cost of communications will not, therefore, completely eliminate Internet-enabled misinformation. Only not inventing the Internet in the first place could have done that. 